\title{
Treatment and use of air pollution control residues from MSW incineration: An overview
}

\author{
Margarida J. Quina $^{\text {a,* }}$, João C. Bordado ${ }^{\text {b }}$, Rosa M. Quinta-Ferreira ${ }^{\text {a }}$ \\ a GERSE-Group on Environment, Reaction and Separation Engineering, Department of Chemical Engineering, University of Coimbra, \\ Polo II- Rua Sílvio Lima, 3030-790 Coimbra, Portugal \\ ${ }^{\mathrm{b}}$ Department of Chemical and Biological Engineering, Instituto Superior Técnico, Av. Rovisco Pais, 1049-001 Lisboa, Portugal
}

Accepted 22 August 2007

\begin{abstract}
This work reviews strategies for the management of municipal solid waste incineration (MSWI) residues, particularly solid particles collected from flue gases. These tiny particles may be retained by different equipment, with or without additives (lime, activated carbon, etc.), and depending on the different possible combinations, their properties may vary. In industrial plants, the most commonly used equipment for heat recovery and the cleaning of gas emissions are: heat recovery devices (boiler, superheater and economiser); dry, semidry or wet scrubbers; electrostatic precipitators; bag filters; fabric filters, and cyclones. In accordance with the stringent regulations in force in developed countries, these residues are considered hazardous, and therefore must be treated before being disposed of in landfills. Nowadays, research is being conducted into specific applications for these residues in order to prevent landfill practices. There are basically two possible ways of handling these residues: landfill after adequate treatment or recycling as a secondary material. The different types of treatment may be grouped into three categories: separation processes, solidification/stabilization, and thermal methods. These residues generally have limited applications, mainly due to the fact that they tend to contain large quantities of soluble salts $(\mathrm{NaCl}, \mathrm{KCl}$, calcium compounds), significant amounts of toxic heavy metals $(\mathrm{Pb}, \mathrm{Zn}, \mathrm{Cr}, \mathrm{Cu}, \mathrm{Ni}, \mathrm{Cd})$ in forms that may easily leach out, and trace quantities of very toxic organic compounds (dioxin, furans). The most promising materials for recycling this residue are ceramics and glass-ceramic materials.

The main purpose of the present paper is to review the published literature in this field. A range of studies have been summarized in a series of tables focusing upon management strategies used in various countries, waste composition, treatment processes and possible applications.
\end{abstract}

(C) 2007 Elsevier Ltd. All rights reserved.

\section{Contents}

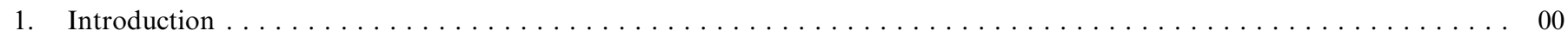

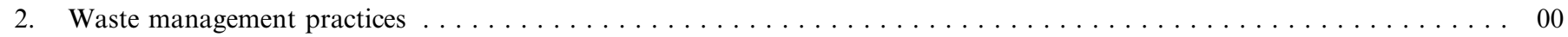

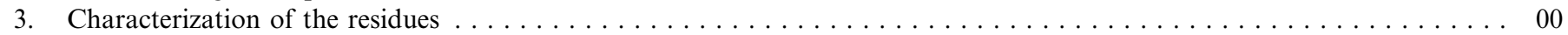

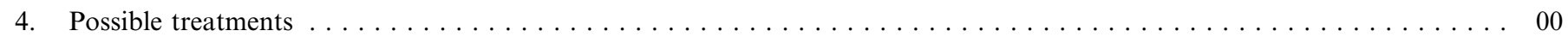

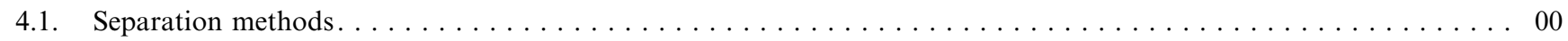

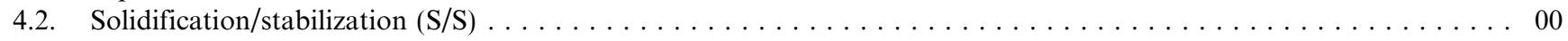

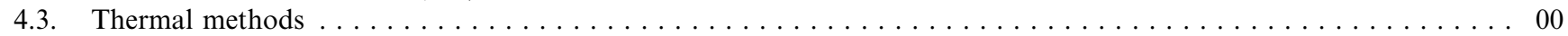

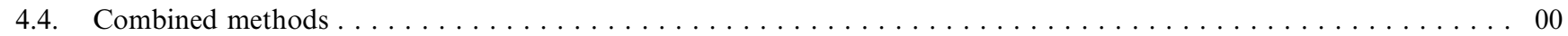

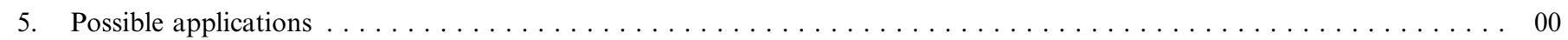

\footnotetext{
${ }^{*}$ Corresponding author. Tel.: +351 239798 721; fax: +351 239798703.

E-mail addresses: guida@eq.uc.pt (M.J. Quina), jcbordado@ist.utl.pt (J.C. Bordado), rosaqf@eq.uc.pt (R.M. Quinta-Ferreira).
} 


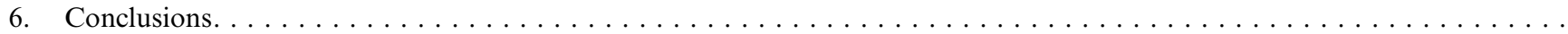

Acronyms

$\begin{array}{ll}\text { APC } & \text { air pollution control } \\ \text { BA } & \text { bottom ashes } \\ \text { CA } & \text { cyclone ash } \\ \text { CB } & \text { chlorobenzenes } \\ \text { DS } & \text { dry scrubbing residues } \\ \text { ESP } & \text { electrostatic precipitator ash } \\ \text { FA } & \text { fly ashes } \\ \text { FF } & \text { fabric filter or baghouse ash } \\ \text { IAWG } & \text { international ash working group } \\ \text { LWA } & \text { lightweight aggregates } \\ \text { MSW } & \text { municipal solid waste } \\ \text { MSWI } & \text { municipal solid waste incineration } \\ \text { PAH } & \text { polycyclic aromatic hydrocarbons } \\ \text { PCB } & \text { polychlorinated biphenyls } \\ \text { PCDD } & \text { polychlorinated dibenzo-p-dioxins } \\ \text { PCDF } & \text { polychlorinated dibenzo furans } \\ \text { S/S } & \text { solidification/stabilization } \\ \text { SDS } & \text { semi-dry scrubbing residues } \\ \text { WS } & \text { wet scrubbing residues }\end{array}$

\section{Introduction}

The solid particles produced during municipal solid waste incineration (MSWI) in mass burning units may be grouped into bottom ashes (BA) and fly ashes (FA). Fly ashes are defined by the International Ash Working Group (IAWG, 1997) as "the particulate matter carried over from the combustion chamber and removed from the flue gas stream prior to addition of any type of sorbent material'. Incorrect terms are sometimes used in the literature when it is appropriate to identify the ash according to the unit that contributes to the waste (Sabbas et al., 2003). In our assessment, only studies using the following terminology have been taken into account:

- Heat recovery system ash, which is collected in hoppers below the boiler, superheater and economiser (sometimes referred to as fly ash - FA);

- Electrostatic precipitator ash (ESP);

- Fabric filter or baghouse ash (FF);

- Dry scrubbing residues (DS), semi-dry scrubbing residues (SDS) or wet scrubbing residues (WS), with sorbents such as $\mathrm{Na}_{2} \mathrm{CO}_{3}, \mathrm{Ca}(\mathrm{OH})_{2}$ and activated carbon;

- Cyclone ash (CA);

- Air pollution control (APC) residues, which may include FA and the solid material captured downstream from the acid gas treatment units and before the gases are released into the atmosphere.
Therefore, the solid waste considered here consists mainly of particles produced in mass burning units, which are carried over by flue gases with or without chemical additives (sorbents). It includes combinations from different units, which will be referred to in the next sections as FA, ESP, FF, DS, SDS, WS, CA and APC residues.

Environmental legislation is becoming increasingly restrictive, and consequently industrial plants have to be constantly adapted to enhance control of gas emissions, in particular. Depending on the units used for post-combustion control, the resulting solid waste may have different characteristics, which means that different management strategies may be used. The next sections examine the strategies adopted in some countries where incineration processes are generally used for the management of MSW, and discuss the treatment and application of possible wastes (FA, ESP, FF, DS, SDS, WS, CA, APC). Some directions for future research in this field will also be suggested.

\section{Waste management practices}

Systems of integrated waste management may include the processes indicated in Fig. 1 (Sabbas et al., 2003). Recycling is generally agreed to be the best management strategy for waste that has already been created and collected, since it transforms the residue into a secondary raw material. However, while the utilization of waste is usually possible and desirable, the emissions produced during the life cycle of the new product should be carefully taken into account. According to the environmental policies of developed countries, disposal in landfills should be avoided as much as possible.

The present overview considers the solid residues produced during MSWI and carried over by the flue gases, summarized in Fig. 2. For each tonne of MSW that is incinerated in a mass burn unit, $15-40 \mathrm{~kg}$ of hazardous waste is produced, requiring further treatment and landfill as hazardous waste. Valorization may be an alternative, but it is important to ensure that the environment is properly protected against emissions into the earth, water and atmosphere. Since APC residues include the particulate matter captured after the acid gas treatment units, the waste may be a solid or a sludge, depending on the type of air pollution control equipment used (dry, semi-dry or wet processes), and is generally characterized by high concentrations of salts, heavy metals and organic trace-pollutants. These properties limit subsequent applications and require pre-treatment to improve their environmental characteristics. One of the most usual strategies for the manage- 


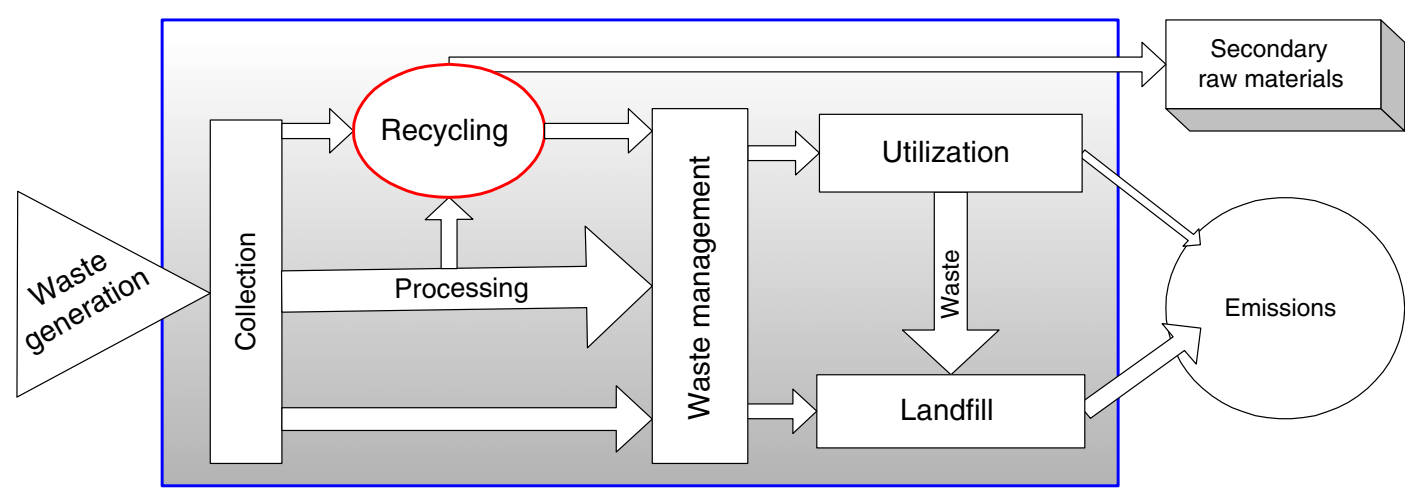

Fig. 1. Integrated waste management system, based on Sabbas et al. (2003).

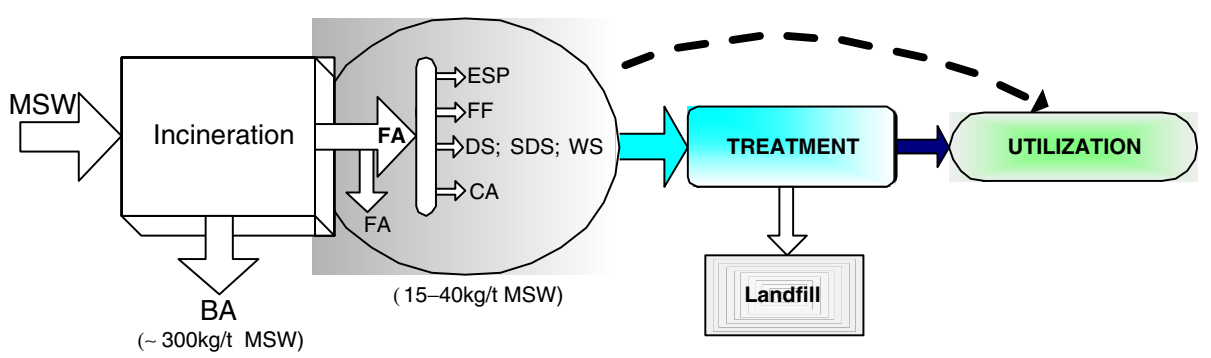

Fig. 2. Management of APC residues from MSW incineration.

ment of these APC residues is treatment followed by landfill.

In practice (as indicated in Table 1), the most common options for the management of fly ash/APC residues are permanent storage in hazardous waste disposal sites or treatment followed by disposal with less stringent requirements. Temporary storage in big bags or disposal in underground sites are alternatives in some countries. Van der Sloot et al. (2001) claims that the beneficial utilization of residues from municipal solid waste incineration is an

Table 1

Waste management of FA/APC residues from MSWI processes in various countries

\begin{tabular}{ll}
\hline Country & Management strategies for FA/APC residues \\
\hline USA & APC residues and bottom ash are mixed at most MSW incineration (MSWI) plants and disposed as a \\
& "combined ash". The most frequent dumping option is disposal in landfills which receive only MSWI residues \\
(monofills)
\end{tabular}

Canada

Sweden

Denmark

APC residues are disposed in a hazardous waste landfill after treatment

APC residues are disposed in secure landfills after treatment

APC residues and fly ashes are classified as a special hazardous waste and are currently exported or stored temporarily in big bags. Significant efforts are being spent to develop treatment methods which can guarantee that APC residues can be landfilled in a sustainable way

Germany The APC residues are mainly disposed of in underground disposal sites, such as old salt mines

Netherlands Flue-gas cleaning wastes are disposed temporarily in large sealed bags at a controlled landfill until better options are available. The utilization of APC residues is presently not considered. The re-use of the waste is subject to investigation

France After industrial solidification and stabilization processes based on the properties of hydraulic binders, the waste is stored in confined cavities in a specific landfill (French class I and II). The high cost of this treatment is promoting the companies to search alternatives to disposal

Italy Various technologies have been proposed, but the most widely adopted comprehends solidification with a variety of hydraulic binders (such as cement and/or lime, blast furnace slag, etc.)

Portugal APC residues are treated with hydraulic binders (solidification/stabilization method) and landfilled in specific sites (monofills)

Japan $\quad$ MSWI fly ash and APC residues are considered as hazardous, and before landfill intermediate treatments must be performed, such as melting, solidification with cement, stabilization using chemical agents or extraction with acid or other solvents. Melting slag may be used in road construction and the materials of S/S with cement are landfilled
Reference

Eighmy and Kosson (1996)

Sakai et al. (1996)

Millrath et al. (2004)

Sakai et al. (1996)

Sakai et al. (1996)

Hjelmar

(1996a,1996b)

Sorensen et al. (2001)

Vehlow (1996)

IEA (2000)

Van der Sloot (1996)

Piantone et al. (2003)

Polettini et al. (2001)

Quina (2005)

Sakai (1996)

Nagib and Inoue

(2000)

Ecke et al. (2000) 
important goal for integrated waste management in some jurisdictions. However, the most significant potential environmental problems related to the disposal of MSWI residues are the short- and long-term leaching of contaminants (Hjelmar, 1996b). In particular, the high soluble salt content will be very difficult to stabilize in disposed waste without prior or simultaneous removal by aqueous extraction. In fact, removing salts makes the remaining inorganic residue much more manageable (van der Sloot et al., 2001). In a recent paper, the management of BA, FA and APC residues produced in Flanders, The Netherlands, Germany and France were compared, taking into account heavy metal contamination (Van Gerven et al., 2005). The main conclusion was that these residues may be managed differently in different countries, in accordance with management options available, leaching tests and limit values. In fact, European limit values for landfills have only become available recently, while recycling legislation has not been developed yet.

Some authors have stressed that the improvement of air pollution control devices shifts the focus from air emissions to incinerator residues (Sawell et al., 1995).

\section{Characterization of the residues}

In order to select the most appropriate method of treatment or application for any residue, it is extremely important to know its main characteristics, particularly chemical properties. Some physical characteristics may also be very important in some cases. Table 2 indicates the total contents of several elements and some organic compounds that were measured in diverse studies. Those compositions show that the major elements are $\mathrm{Si}, \mathrm{Al}, \mathrm{Fe}, \mathrm{Ca}, \mathrm{Mg}, \mathrm{K}$, $\mathrm{Na}$ and $\mathrm{Cl}$. As regards heavy metals, $\mathrm{Cd}, \mathrm{Cr}, \mathrm{Cu}, \mathrm{Hg}, \mathrm{Ni}$, $\mathrm{Pb}$ and $\mathrm{Zn}$ were the most frequent, with $\mathrm{Zn}$ and $\mathrm{Pb}$ generally found in the largest amounts. Trace quantities of very toxic organic compounds are usually present in these residues, namely polycyclic aromatic hydrocarbons $(\mathrm{PAH})$, chlorobenzenes (CB), polychlorinated biphenyls (PCB) and polychlorinated dibenzo- $p$-dioxins (PCDD) and furans (PCDF).

Whenever the treatment, utilization or disposal of APC residues are considered, both $\mathrm{Pb}$ and $\mathrm{Cl}-$ are of particular concern due to their leaching behaviour; Figs. 3 and 4 show the ranges of elemental composition for those species, based on the literature. It should be noted that some of these studies correspond to comprehensive analysis, where diverse properties are also indicated (Le Forestier and Libourel, 1998; Alba et al., 2001; Bodénan and Deniard, 2003; Li et al., 2003a, 2004). Additional works may also be referred in the context of characterization of the considered residues (Sawell et al., 1999; van der Sloot et al., 2001; Song et al., 2004; He et al., 2004; Geysen et al., 2006; Quina et al., 2007). Those (Figs. 3 and 4) were obtained from different residues (APC, FA, DS, SDS, WS, CA and FF) produced in several countries (Belgium, China, Denmark, France, Germany, Italy, Japan, Korea, Portugal, Spain, Taiwan, The Netherlands). An asterisk (*) in the caption of these fig- ures means that the country of origin or type of residue being studied is not clear in the reference. The shaded area (Ref. b.1-b.3, c.1-c.3, d) correspond to typical ranges indicated in some references that review various other studies. By comparing the data for $\mathrm{Pb}$ (Fig. 3) from the shaded area (Hjelmar, 1996b; IAWG, 1997; Stegemann and Buenfeld, 2003), it can be concluded that, depending on the residues in question, the range may be very wide for this element. A glance at Fig. 3 shows that the amount of $\mathrm{Pb}$ in these residues may be lower than $1000 \mathrm{mg} / \mathrm{kg}$ or higher than 10,000 $\mathrm{mg} / \mathrm{kg}$. The concentration of $\mathrm{Pb}$ in the APC residues from Portugal is $1495-2453 \mathrm{mg} / \mathrm{kg}$, which is lower than the ranges indicated in Hjelmar (1996b) and IAWG (1997) for similar residues. In studies conducted by the authors (Quina, 2005; Quina et al., 2007), the chloride concentration measured in 5 samples taken over 2.5 years was $101-138 \mathrm{~g} /$ $\mathrm{kg}$, which is a considerable amount for APC residues. Nevertheless, other studies have revealed wider ranges, as in the case of Polettini et al. (2001), where the indicated amount of chloride may be $29-337 \mathrm{~g} / \mathrm{kg}$. These variations make it difficult to treat waste on the basis of general formulations. Therefore, careful characterization studies should precede any treatment or valorization procedure.

For many applications, particularly ceramics and glassceramics, it is important to know the quantities of oxide species. Some of the values given in the literature for $\mathrm{CaO}, \mathrm{SiO}_{2}, \mathrm{Al}_{2} \mathrm{O}_{3}, \mathrm{Fe}_{2} \mathrm{O}_{3}, \mathrm{MgO}, \mathrm{Na}_{2} \mathrm{O}, \mathrm{K}_{2} \mathrm{O}, \mathrm{Ti}_{2} \mathrm{O}, \mathrm{SO}_{3}$, $\mathrm{P}_{2} \mathrm{O}_{5}, \mathrm{MnO}$ and $\mathrm{ZnO}$ are indicated in Table 3. Oxide compositions are also given in many other studies, such as Quina et al. (2006), Qian et al. (2006a,b), Park et al. (2005), Carignan et al. (2005), Chimenos et al. (2005), Stegemann and Buenfeld (2003), Wang et al. (2002, 2004), Rémond et al. (2002a), Nishida et al. (2001), Polettini et al. (2001), Haugsten and Gustavson (2000) and Derie (1996). Although oxide composition may vary, a very high alkali content is generally observed, mainly due to the calcium hydroxide or sodium carbonate usually used for acid gas removal. Consequently, the natural $\mathrm{pH}$ of these residues is usually also very high, sometimes higher than 12.5 , which may constitute a problem for some applications. It should be noted that 12.5 is the $\mathrm{pH}$ value of a saturated solution of $\mathrm{Ca}(\mathrm{OH})_{2}$.

As indicated in Table 2, APC residues mainly consist of $\mathrm{O}, \mathrm{Si}, \mathrm{Ca}, \mathrm{Al}, \mathrm{Cl}, \mathrm{K}, \mathrm{Na}, \mathrm{S}$ and $\mathrm{Fe}$, and are mostly present as oxides (shown in Table 3), chlorides, sulphates and carbonates (Hong et al., 2000; IAWG, 1997; Wiles, 1996). However, due to the high concentration of several heavy metals, the reuse of APC residues as a secondary material is prohibited in many countries, with the ever more stringent legislation. Therefore, taking into account the potential environmental impact of these residues, the main problems that have to be solved concern toxic heavy metals (e.g., $\mathrm{Pb}, \mathrm{Zn}, \mathrm{Cd}, \mathrm{Cr}, \mathrm{Cu}, \mathrm{Ni}, \mathrm{Hg}$ ), the high concentration of soluble salts (e.g., $\mathrm{NaCl}, \mathrm{KCl}$, salts of $\mathrm{Ca}$ ), and organic micropollutants (e.g., dioxins, furans). Among other researchers, Hjelmar (1996b) pointed out that almost all APC residues produced are landfilled or placed in under- 
Table 2

Total composition of FA/APC MSWI residues based on literature

IAWG (1997) Le Forestier and Libourel (1998)

Song et al. (2004) Eighmy et al. (1995)

$45-83$

APC +FA

FA

APC + FA

$\begin{array}{ll}\mathrm{g} / \mathrm{kg} & 12 \\ \mathrm{~g} / \mathrm{kg} & 4 \\ \mathrm{~g} / \mathrm{kg} & \end{array}$

$12-40$
$4-16$

$57-98$

95-190

12-83

$49-78$
$18-35$

$17-46$
$3.6-18$

92-36
nd

$3.6-18$
$170-290$

74-130

$7.1-12$

11-19

23-30

$\mathrm{g} / \mathrm{kg}$

$22-33$

nd

27-40

12-19

$1.5-5.1$

22-57

$7.5-12$

$8-18$

101-138

$\mathrm{g} / \mathrm{kg}$

nd

92-220

1.7-4.6

nd

$0.3-0.7$

$14-60$

40-260

310-1400

$0.5-0.9$

nd

$\mathrm{mg} / \mathrm{kg}$

49-87

$\mathrm{mg} / \mathrm{kg}$

nd

72-259

440-648

$140-300$

4-15

$\mathrm{mg} / \mathrm{kg}$

9-16

150-570

$450-1100$

$9.3-44$

nd

$\mathrm{mg} / \mathrm{kg}$

45-132

$\mathrm{mg} / \mathrm{kg}$

1495-2453

9.3-20

20-63

4000-6500

$8.2-16$

$\mathrm{mg} / \mathrm{kg}$

nd

620-780

$\mathrm{mg} / \mathrm{kg}$

nd

400-500

26-62

11-32

45-101

4.8-9.6

$0.8-1.7$

31-95

49-320
$920-1800$

nd

230-430

29-69

$140-530$
$860-1400$

$0.8-7$

2.6-71

110-350

5.1-14

5.9-40

7.6-29

$0.7-5.7$

1.4-25

62-380

1.7-4.6

$0.2-0.9$

0.9-60

18-530

51-14000

$0.5-0.9$

140-300

73-570

16-1700

$0.1-51$

15-49

95-240

7400-19000

9.3-29

6.1-31

1400-1900

2500-1000

620-1400

400-500

32-150

12000-19000

19000-41000

$8-62$

4308-6574 $\quad 12000-19000 \quad 19000-41000 \quad 7000-20000$

18-5600

$30-110$

$<40$

$0.7-1000$

1.4-370

$<40$

$115-140$

$0.8-2$

48-69

30

$0.03-0.4$

nd

$0.7-32$

6-9

1.5-2.5

1.4-73

$12-24$

28-49

11-43

$0.8-2$

21-120

\begin{tabular}{l}
\hline SD \\
56 \\
36
\end{tabular}

36
8.4
274

274

9.8

17
15

15
4.4

4.4
11

183

3.2

nd

19
804

804
nd

126

126
10

217
434

434

18

nd
52

52
2780

nd

814

814
337

337
38

38
8211

ESP

$\begin{array}{llll}\text { ESP } & \text { SDS } & \text { FF } & \text { ESP } \\ 132 & \text { nd } & \text { nd } & 38 \\ 93 & 10 & 6.4 & 21 \\ 12 & 2.0 & 0.76 & 1.6 \\ 169 & 117 & 65 & 46\end{array}$

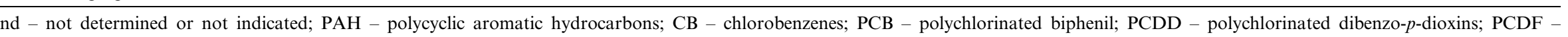

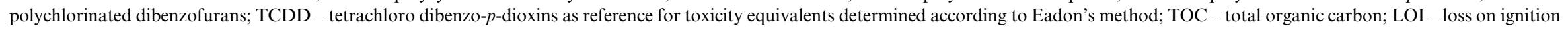
$\left(550^{\circ} \mathrm{C}\right) ; \mathrm{SD}$ - semi-dry absorber; $\mathrm{BF}$ - bag filter. 


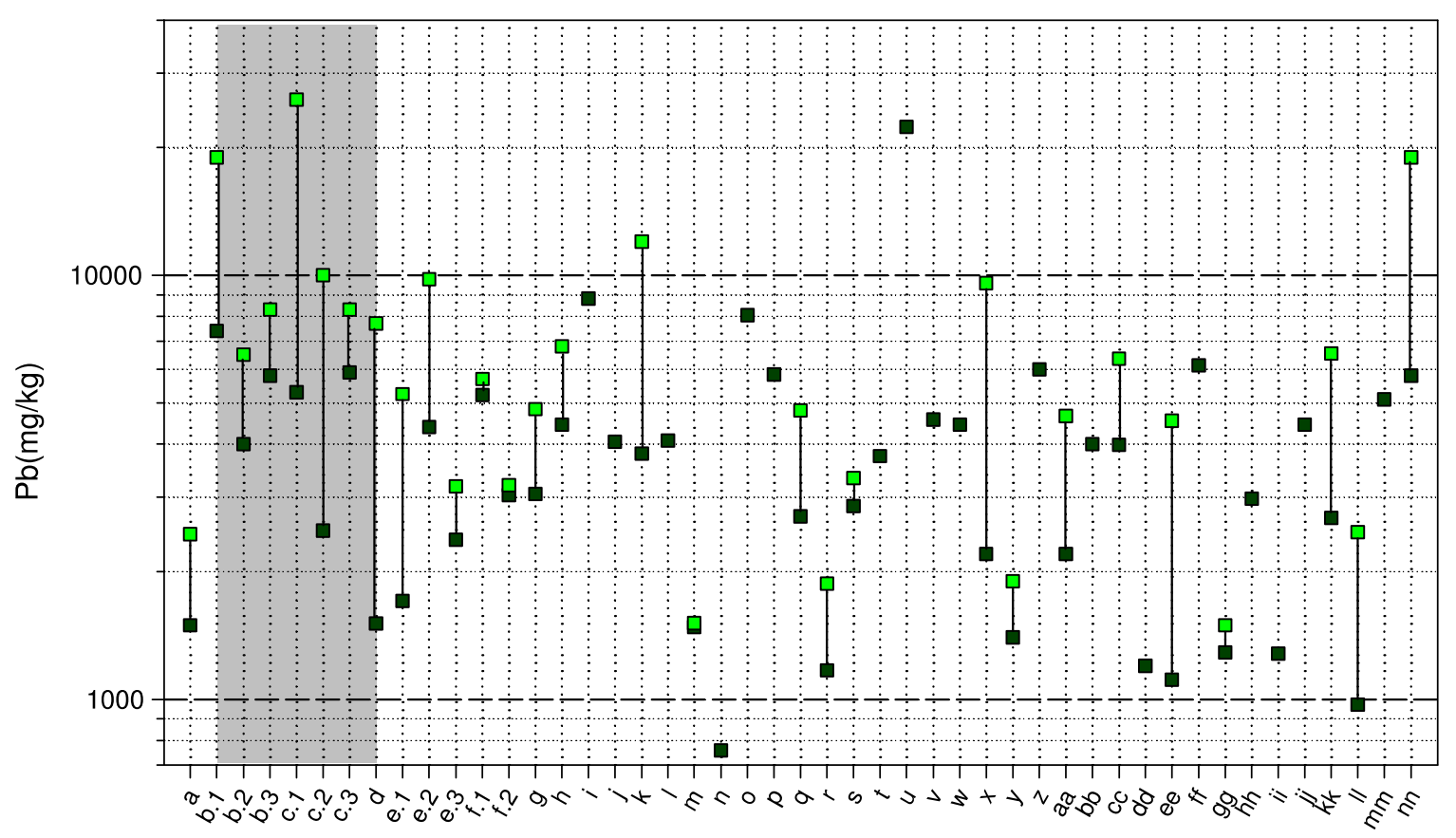

a- Quina (2005)

b.1- Hjelmar (1996b)

b.2- Hjelmar (1996b)

b.3 - Hjelmar (1996b)

c.1- IAWG (1997)

c.2- IAWG (1997)

c.3- IAWG (1997)

d- Stegemann and Buenfeld (2003) FA (APC)- Usual range

e.1 - Le Forestier and Libourel (1998) ESP- France

e.2- Le Forestier and Libourel (1998) SDS (no ESP)- France

e.3- Le Forestier and Libourel (1998) SDS- France

f.1 - Alba et al (2001)

f.2- Alba et al (2001)

g- Geysen et al (2004b)

h- Li et al (2003a)

i- Aubert et al (2004)
APC -Portugal

FA -Usual range

SDS/DS- Usual range

WS- Usual range

FA- Usual range

SDS/DS- Usual range

WS - Usual range

FA- Spain $\left(^{*}\right)$

APC- Spain $(*)$

$\mathrm{APC}(\mathrm{SD}+\mathrm{FF})-$ Belgium

FA (APC*)- China

FA (APC*)- France

$\begin{array}{ll}\text { j- Chimenos et al (2005) } & \text { FF- Spain } \\ \text { k- Derie (1996) } & \text { FA (APC*) -Belgium France } \\ \text { 1- Piantone et al (2003) } & \text { FA (APC*)- Belgium } \\ \text { m- Youcai et al (2002) } & \text { FF- China } \\ \text { n- Park and Heo (2002a) } & \text { ESP- Korea } \\ \text { o- Pedersen (2002) } & \text { ESP- Denmark } \\ \text { p- Wunsch et al (1996) } & \text { ESP- Germany }\left(^{*}\right) \\ \text { q- Izumikawa (1996) } & \text { FA(APC*)- Japan }\left(^{*}\right) \\ \text { r- Jianguo et al (2004) } & \text { APC- China } \\ \text { s- Jung et al (2005) } & \text { FA(APC*)- Japan } \\ \text { t- Kamon et al (2000) } & \text { ESP- Japan } \\ \text { u- Katsuura et al (1996) } & \text { ESP- Japan } \\ \text { v- Kuo et al (2004) } & \text { APC- Taiwan } \\ \text { w- Li et al (2004) } & \text { ESP- China } \\ \text { x- Mangialard (2001) } & \text { FA (APC*)- Italy } \\ \text { y- Mizutani et al (1996) } & \text { APC - Japan }\end{array}$

z- Mulder (1996)

aa- Polettini et al (2001)

bb- Rémond et al (2002a)

cc- Lundtorp et al (200 )

dd- Nagib and Inoue (2000)

ee- Song et al (2004)

ff- Ubbriaco et al (1998)

gg- Wang et al (2001)

hh- Wang et al (2002)

ii- Wang et al (2004)

jj- Yang and Tsai (1998)

kk- Carignan et al (2005)

11- He et al (2004)

mm- Park et al (2005)

nn- Sorensen et al (2001)
FA (APC*)- Netherlands

ESP; FF- Italy

APC (WS)- France

DS; ESP- Denmark

ESP- Japan

WS; SD; FF- South Korea

ESP- Italy

CA- Taiwan

CA- Taiwan

CA- Taiwan

CA- Taiwan

FA, ESP, DS, FF- France

APC- China

FA (APC*)- Korea

APC, ESP- Denmark

Fig. 3. Lead concentration in incineration residues from MSWI (APC, FA, DS, SDS, WS, ESP, FF, CA).

ground facilities, and because of the potential leaching of contaminants over long periods, the solutions chosen for these residues should be sustainable in terms of environmental impact.

\section{Possible treatments}

The appropriate treatments for APC residues can be grouped into three classes (IAWG, 1997): (i) separation processes; (ii) solidification/stabilization (S/S); (iii) thermal methods. Fig. 5 shows a scheme of this classification, where further subdivisions for each type of treatment is also indicated. In practice, it may be useful to start the treatment with separation techniques (mainly washing or leaching with fluid solutions that are more aggressive than water), followed by thermal treatments or stabilization/solidification methods. As pointed out by Sabbas et al. (2003), treatment strategies may vary; methodologies for reducing environmental impact may involve lowering the total content of the contaminant (e.g., through washing), reducing the availability of contaminants for leaching (e.g., by stabilization methods), or decreasing the leaching rates (e.g., through S/S methods). Van der Sloot et al. (2001) present an overview of the methods of treatment for MSWI residues, indicating those which correspond to existing proven technology, those that have shown promising results, and the ones that are currently under investigation or have been found to be technically and/or economically feasible. Sakai et al. (1996) stressed that, in comparing different technologies, a cost assessment is needed in addition to a description of the characteristics of the products generated by each process. The high costs associated with vitrification or extraction processes may be considered acceptable if the potential use or volume reduction of the material being generated is taken into account. On the other hand, the lower costs of $\mathrm{S} / \mathrm{S}$ methods must be counterbalanced by the shortcomings of the significant volume increase due to the need for solidification reagents (binders) and the potential long-term instability (mainly the high salt contents) of the treated material. 


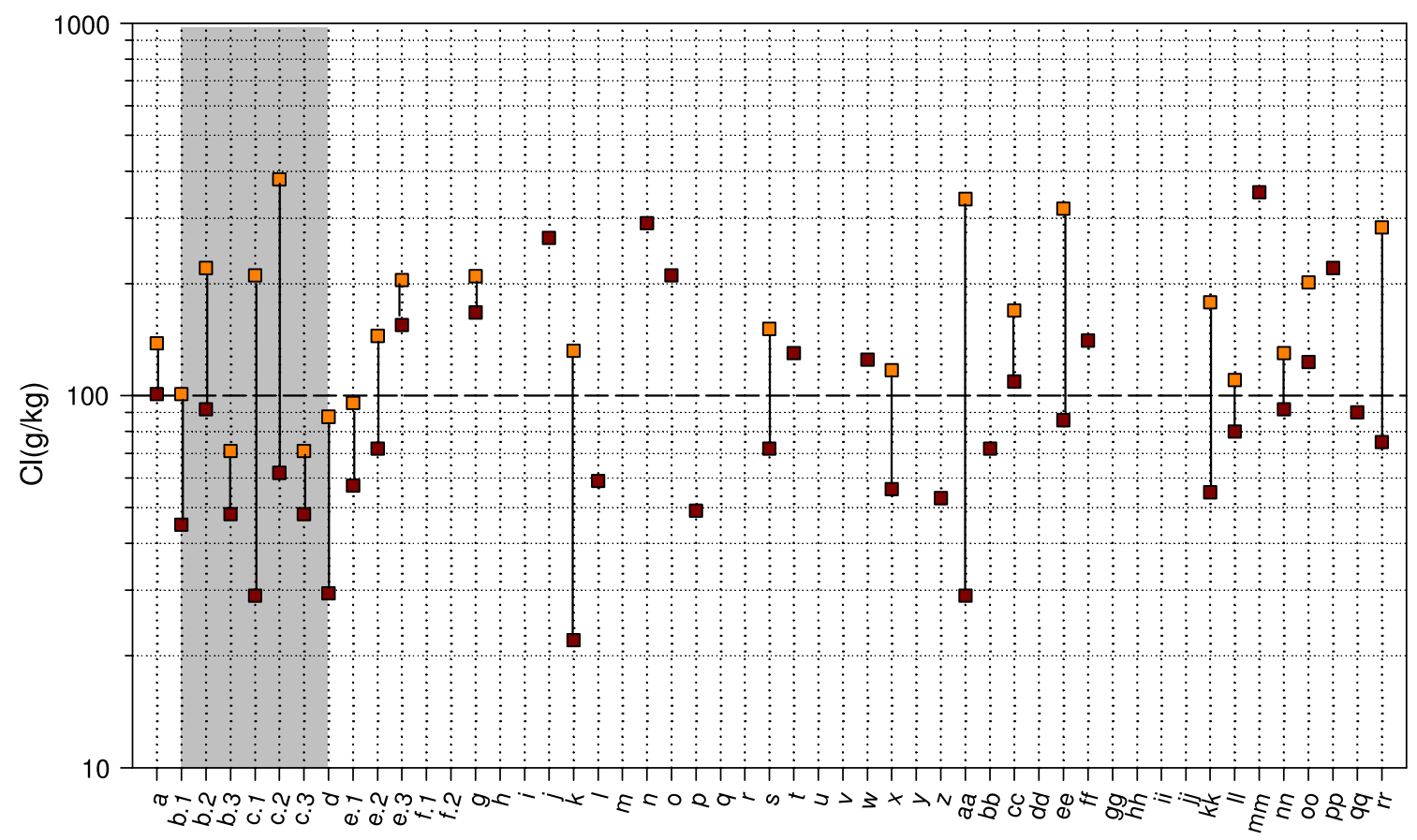

a- Quina (2005)

b.1- Hjelmar (1996b)

b.2- Hjelmar (1996b)

b.3-Hjelmar (1996b)

c.1- IAWG (1997)

c.2- IAWG (1997)

c.3- IAWG (1997)

e.1- Le Forestier and Libourel (1998) ESP- France

e.2- Le Forestier and Libourel (1998) SDS (no ESP)- France

e.3- Le Forestier and Libourel (1998) SDS- France

f.1 - Alba et al (2001)

f.2- Alba et al (2001)

g- Geysen et al (2004b)

h- Li et al (2003a)

i- Aubert et al (2004)

j. Chimenos et al (2005)
APC- Portugal

FA- Usual range

SDS/DS- Usual range

WS- Usual range

FA- Usual range

SDS/DS- Usual rang

WS- Usual range

FA- Spain $(*)$

$\operatorname{APC}$ - Spain $(*)$

$\mathrm{APC}$ (SD+FF)- Belgium

FA (APC*)- China

FA (APC*)- France

FF- Spain

\begin{tabular}{|l} 
k- Derie (1996) \\
l- Piantone et al (2003) \\
m- Youcai et al (2002) \\
n- Park and Heo (2002a) \\
o- Pedersen (2002) \\
p- Wunsch et al (1996) \\
q- Izumikawa (1996) \\
r- Jianguo et al (2004) \\
s- Jung et al (2005) \\
t- Kamon et al (2000) \\
u- Katsuura et al (1996) \\
v- Kuo et al (2004) \\
w- Li et al (2004) \\
x- Mangialard (2001) \\
y- Mizutani et al (1996) \\
z- Mulder (1996) \\
aa- Polettini et al (2001)
\end{tabular}

FA (APC*)- Belgium, France

FA (APC*)- Belgium

FF- China

ESP- Korea

ESP- Denmark

ESP- Germany $(*)$

FA(APC*)- Japan(*)

APC-China

FA(APC*)- Japan

ESP- Japan

ESP- Japan

APC- Taiwan

ESP- China

FA (APC*)- Italy

APC - Japan

FA (APC*)- Netherlands

ESP; FF- Italy bb- Rémond et al (2002a) APC (WS)- France cc- Lundtorp et al (2003) DS; ESP- Denmark dd- Nagib and Inoue (2000) ESP- Japan ee- Song et al (2004) WS; SD; FF- South Korea ff- Ubbriaco et al (1998) ESP- Italy gg- Wang et al (2001) CA- Taiwan hh- Wang et al (2002) CA- Taiwan ii- Wang et al (2004) CA- Taiwan jj- Yang and Tsai (1998) CA- Taiwan kk- Carignan et al (2005) FA, ESP, DS, FF- France 11- He et al (2004) mm- Park et al (2005) nn- Sorensen et al (2001) oo- Qian et al (2006a,b) pp- Kim and Kim (2004 qq- Iretskaya et al (1999) rr- Bodénan and Deniard (2003) APC- Several countries

Fig. 4. Chloride concentration in incineration residues from MSWI (APC, FA, DS, SDS, WS, ESP, FF, CA).

In the literature, the cost of the different treatments is seldom indicated. Ecke et al. (2000) claim that thermal processes may involve costs of over $367 € \mathrm{t}^{-1}$, which is a com- pletely different order of magnitude to the other processes. In fact, since melting methods involve expensive equipment and high energy input, operating costs may be as much as

Table 3

Chemical composition of the major oxides that constitute the APC residues (wt.\%)

\begin{tabular}{|c|c|c|c|c|c|c|c|c|c|c|c|}
\hline & \multirow{2}{*}{$\begin{array}{l}\text { Auer et al. } \\
(1995) \\
\text { ESP }\end{array}$} & \multicolumn{2}{|c|}{$\begin{array}{l}\text { Alba et al. } \\
\text { (1997) }\end{array}$} & \multirow{2}{*}{$\begin{array}{l}\text { Romero } \\
\text { et al. (2001) } \\
\text { FA }\end{array}$} & \multirow{2}{*}{$\begin{array}{l}\text { Li et al. } \\
(2003 a) \\
\text { FA + APC }\end{array}$} & \multirow{2}{*}{$\begin{array}{l}\text { Piantone } \\
\text { et al. (2003) } \\
\text { APC }\end{array}$} & \multicolumn{2}{|c|}{$\begin{array}{l}\text { Song et al. } \\
(2004)\end{array}$} & \multirow{2}{*}{$\begin{array}{l}\text { Cheng and } \\
\text { Chen (2004) } \\
\text { FA }\end{array}$} & \multicolumn{2}{|c|}{$\begin{array}{l}\text { Kim and } \\
\text { Kim (2004) }\end{array}$} \\
\hline & & FA & APC & & & & SDS & $\mathrm{FF}$ & & ESP & ESP_wash \\
\hline $\mathrm{CaO}$ & 19.3 & 24.3 & 27.7 & 29.34 & 13.9 & 24.2 & 52.9 & 25.2 & 19.7 & 19.50 & 26.23 \\
\hline $\mathrm{SiO}_{2}$ & 20.2 & 18.8 & 15.0 & 11.47 & 8.57 & 33.6 & 5.8 & 4.7 & 19.4 & 7.30 & 21.94 \\
\hline $\mathrm{Al}_{2} \mathrm{O}_{3}$ & 12.3 & 12.7 & 7.1 & 5.75 & 3.90 & 11.6 & 2.8 & 1.8 & 10.1 & 3.20 & 9.97 \\
\hline $\mathrm{Fe}_{2} \mathrm{O}_{3}$ & 1.2 & 1.6 & 1.4 & 1.29 & 2.58 & 1.9 & 2.4 & 0.95 & 1.8 & 1.39 & 2.08 \\
\hline $\mathrm{MgO}$ & 2.5 & 2.6 & 1.9 & 3.02 & 3.16 & 2.2 & 2.6 & 1.3 & 2.8 & 2.61 & 8.32 \\
\hline $\mathrm{Na}_{2} \mathrm{O}$ & 6.4 & 5.8 & 4.1 & 8.70 & 14.0 & 2.2 & (a) & 10.9 & 8.9 & 13.07 & 2.11 \\
\hline $\mathrm{K}_{2} \mathrm{O}$ & 6.2 & 4.3 & 4.4 & 7.02 & 8.77 & 2.6 & 1.5 & 10.6 & 8.1 & 11.21 & 0.84 \\
\hline $\mathrm{TiO}_{2}$ & 1.4 & 1.5 & 1.0 & 0.85 & 0.76 & 1.7 & 1.9 & 1.2 & 1.9 & 2.77 & 3.80 \\
\hline $\mathrm{SO}_{3}$ & 8.3 & 6.4 & 8.2 & (a) & 15.36 & (a) & 6.7 & 8.0 & (a) & 9.76 & 11.93 \\
\hline $\mathrm{P}_{2} \mathrm{O}_{5}$ & 1.3 & 2.7 & 1.6 & 1.69 & 2.81 & 1.4 & 1.4 & 1.2 & (a) & 1.72 & 5.76 \\
\hline $\mathrm{MnO}$ & (a) & 0.12 & 0.06 & 0.18 & 0.12 & 0.06 & (a) & (a) & (a) & (a) & (a) \\
\hline $\mathrm{ZnO}$ & 3.0 & (a) & (a) & (a) & (a) & (a) & (a) & (a) & (a) & 3.02 & 4.72 \\
\hline
\end{tabular}

ESP - electrostatic precipitator; FA - fly ash; APC - air pollution control residues; SDS - semi-dry absorber; FF - bag filter; (a) - not indicated. 


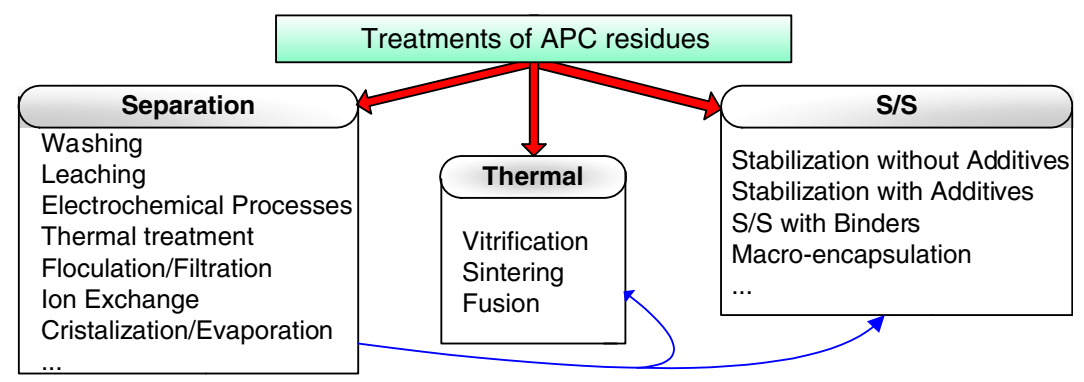

Fig. 5. Treatments for APC residues.

15 times higher than cementitious solidification/stabilization $(\mathrm{S} / \mathrm{S})$ processes. On the other hand, the addition of $2-3$ wt.\% of chelate agents in stabilization methods may result in a cost of $61-92 € \mathrm{t}^{-1}$. Chemical treatments are generally more expensive than cementitious $\mathrm{S} / \mathrm{S}$, but the increase in solid waste mass is lower. Therefore, if disposal costs are taken into account in this less expensive technology, separation methods such as acid extraction might be possible options, with the advantage that they enable the recovery of metals and salts. Alternative inorganic binding agents, when compared with ordinary Portland cement, may lead to treatment costs two to three times higher than for cementitious $\mathrm{S} / \mathrm{S}$. Based on industrial data from a Portuguese industrial incineration plant and excluding the landfill cost, the cementitious $\mathrm{S} / \mathrm{S}$ treatment may cost $45 € \mathrm{t}^{-1}$ (Quina, 2005).

\subsection{Separation methods}

Separation methods include all techniques that allow the extraction of some species from the waste, aiming to improve the quality of the residue for further utilization and/or to recover the species in question. According to Mohapatra and Rao (2001), acid leaching, alkali fusion, ion exchange, solvent extraction and magnetic separation are some of the most widely used methods for extracting metal values from different types of fly ash. For APC residues from MSW incineration, several separation processes may also be applied (Fig. 5):

(1) Washing processes: The objective in this case is generally to remove the soluble salts by using water as a leachant. This process may be used as a first step in more elaborate methodologies (Chimenos et al., 2005; Mangialardi, 2003; Piantone et al., 2003; Nzihou and Sharrock, 2002; Krebs et al., 2001; Lundtorp et al., 2003; Derie, 1996; Mulder, 1996). Kirby and Rimstidt (1994) studied the dominant chemical reactions between water and a mixture of ESP and bottom ash (BA), and concluded that $10 \mathrm{~kg}$ of anhydrous salts can be obtained from a tonne of waste. Studies by the author have shown that washing methods involving water alone are not very appropriate since large quantities of heavy metals (e.g., $\mathrm{Pb}$ and $\mathrm{Zn}$ ) are also released simultaneously with the soluble salts (Quina, 2005). Some chemical additives, such as soluble phosphates, may be used to overcome this problem.

(2) Leaching: Aiming at the extraction of heavy metals for further recovery, leachant solutions other than water may be used. The main elements in this process are $\mathrm{Pb}$ and $\mathrm{Zn}$, and the goal is to obtain a solution in which concentrations are high enough to enable further separation or recovery. When the released amounts are too low, two possibilities can be implemented for improving leaching efficiency: adding chemical additives or reintroducing the leachate into the process (Laethem et al., 1994). In the literature, various studies attempted to use chemical agents to improve heavy metal leaching (Hong et al., 2000; van der Bruggen et al., 1998; Katsuura et al., 1996). The efficiency of the extraction depends very much upon the heavy metal in question, the extracting agent, the $\mathrm{pH}$ and the liquid/solid ratio used. In Japan, nine acid extraction units for treating the MSWI residues are in operation (Ecke et al., 2000). According to some studies, the leaching of heavy metals can also be improved through bioleaching, by using bacteria leaching processes (Krebs et al., 2001; Bosshard et al., 1996).

(3) Electrochemical processes: These methodologies involve reduction/oxidation reactions at the interface of electrodes and electrolyte, forced by a potential difference in the electrodes. During the electrochemical process, hydrogen is generated at the cathode, metals are deposited on its surface (through the reduction reaction) and oxygen is released at the anode (due to the oxidation reaction). The main advantage of these methods is that they do not require the addition of chemicals, but removing metals when the concentration is low is a major problem (Yang and Tsai, 1998). The variables that significantly affect this process are current density, temperature, mixing conditions, distance between the electrodes and the $\mathrm{pH}$ of the solution.

(4) Thermal treatment: This method may be used for removing heavy metals through evaporation processes (using temperatures lower than melting point), while at the same time enabling the recycling of the metals (decontamination). In general, the heavy 
metals of interest are $\mathrm{Zn}, \mathrm{Pb}, \mathrm{Cu}$ and $\mathrm{Cd}$. In the literature, some studies have yielded promising results as regards the separation of heavy metals by thermal treatment (Auer et al., 1999; Jakob et al., 1995, 1996; Stucki and Jakob, 1997). The principal thermochemical reactions that control the evaporation of heavy metals are: the evaporation of the metallic forms or reduction at the metal state followed by evaporation; the evaporation of the volatile chlorides, and the formation of stable compounds within the solid matrix, which remain as oxides in the residue (Jakob and Stucki, 1997).

Table 4

Separation processes for treatment of APC residues

\begin{tabular}{|c|c|c|c|c|}
\hline 1Separation & Residue & Objective & Conclusion & Reference \\
\hline \multirow[t]{5}{*}{ Washing } & $\begin{array}{l}\text { ESP } \\
\text { APC }\end{array}$ & $\begin{array}{l}\text { Washing the residue at } \mathrm{pH} 6.5-7.5 \text { and then } \\
\text { solidified with a binder }\end{array}$ & The washed residue is less adverse to cement hydration & $\begin{array}{l}\text { Mangialardi } \\
(2003)\end{array}$ \\
\hline & FF & $\begin{array}{l}\text { Extraction of soluble salts, carried out at a } \mathrm{pH} \\
\text { close to } 10.5 \text { by adding } \mathrm{HCl}\end{array}$ & $\begin{array}{l}\text { Occur carbonation and partial trapping of } \mathrm{Pb} \text { and } \mathrm{Zn} \text { by } \\
\text { calcite neoformed during washing }\end{array}$ & $\begin{array}{l}\text { Piantone } \\
\text { et al. (2003) }\end{array}$ \\
\hline & APC & & & Derie (1996) \\
\hline & APC & Washing with water for extracting soluble salts & $\begin{array}{l}\text { Chlorides can be extracted and the solutions can be } \\
\text { evaporated to produce salts }\end{array}$ & $\begin{array}{l}\text { Nzihou and } \\
\text { Sharrock } \\
(2002)\end{array}$ \\
\hline & $\begin{array}{l}\text { APC } \\
\text { ESP }\end{array}$ & $\begin{array}{l}\text { Washing is promoted through a ferrous-sulphate } \\
\text { solution }\end{array}$ & $\begin{array}{l}\text { A large amount of salts was removed from the residue, } \\
\text { leading to a decrease in leaching }\end{array}$ & $\begin{array}{l}\text { Lundtorp } \\
\text { et al. (2003) }\end{array}$ \\
\hline \multirow[t]{10}{*}{ Leaching } & $\mathrm{FF}$ & $\begin{array}{l}\text { Evaluate the extraction process of metallic } \\
\text { elements from FA under hydrothermal conditions }\end{array}$ & $\begin{array}{l}\text { For a process consisting of two steps (pre-washing and } \\
\text { hydrothermal extraction), the optimum conditions are } \\
150^{\circ} \mathrm{C} \text { and a liquid/solid ratio of } 10: 1\end{array}$ & $\begin{array}{l}\text { Zhang and } \\
\text { Itoh (2006) }\end{array}$ \\
\hline & APC & $\begin{array}{l}\text { Recover } \mathrm{Pb} \text { by using a counter-current sorption } \\
\text { process with peat moss }\end{array}$ & $\begin{array}{l}\text { Peat moss is an excellent adsorbent for } \mathrm{Pb} \text { in alkaline } \\
\text { leachates }\end{array}$ & $\begin{array}{l}\text { Hammy } \\
\text { et al. (2005) }\end{array}$ \\
\hline & $\begin{array}{l}\text { APC } \\
(\mathrm{ESP} \\
\mathrm{FF})\end{array}$ & Recover $\mathrm{Cr}, \mathrm{Cu}, \mathrm{Pb}$ and $\mathrm{Zn}$ by chelating agents & $\begin{array}{l}\text { The residue is detoxified after treatment with chelating } \\
\text { agents }\end{array}$ & $\begin{array}{l}\text { Hong et al. } \\
(2000)\end{array}$ \\
\hline & ESP & $\begin{array}{l}\text { Recover of } \mathrm{Pb} \text { and } \mathrm{Zn} \text { through acid and/or } \\
\text { alkaline leaching }\end{array}$ & Acid leaching is clearly more effective than the alkaline one & $\begin{array}{l}\text { Nagib and } \\
\text { Inoue } \\
(2000)\end{array}$ \\
\hline & ESP & $\begin{array}{l}\text { Simulation of acid extraction in order to remove } \\
\text { heavy metals }\end{array}$ & $\begin{array}{l}\text { For } \mathrm{Pb} \text { an increase in solubility is obtained when EDTA is } \\
\text { added to acid solution }(\mathrm{HCl})\end{array}$ & $\begin{array}{l}\text { Van der } \\
\text { Bruggen } \\
\text { et al. (1998) }\end{array}$ \\
\hline & ESP & Full-scale plant of an acid extraction process & $\begin{array}{l}\text { It is possible to recover solid salts containing near } 99 \% \text { of } \\
\mathrm{NaCl}\end{array}$ & $\begin{array}{l}\text { Katsuura } \\
\text { et al. (1996) }\end{array}$ \\
\hline & APC & $\begin{array}{l}\text { Study the release of metals and availability in } \\
\text { alkali condition }\end{array}$ & The amount extracted depends on the $\mathrm{pH}$ of the solution & $\begin{array}{l}\text { Mizutani } \\
\text { et al. (1996) }\end{array}$ \\
\hline & ESP & $\begin{array}{l}\text { Integrated treatment regarding metal recovery. } \\
\text { The influence on leaching processes of } \mathrm{pH}, L / S \\
\text { and extraction time is analysed }\end{array}$ & $\begin{array}{l}\text { One of the most important factors for leaching processes is } \\
\text { the solubility of the metal salts. Some metals quantities can } \\
\text { decrease for longer extraction times. The solubility of } \mathrm{Pb} \text { and } \\
\mathrm{Cu} \text { can be improved by adding EDTA }\end{array}$ & $\begin{array}{l}\text { Laethem } \\
\text { et al. (1994) }\end{array}$ \\
\hline & ESP & Bioleaching by Aspergillus Niger & $\begin{array}{l}\text { The environmental quality of the residues can be improved } \\
\text { with respect to a re-use }\end{array}$ & $\begin{array}{l}\text { Bosshard } \\
\text { et al. (1996) }\end{array}$ \\
\hline & ESP & Bioleaching by Thiobacilli thiooxidans & $\begin{array}{l}\text { Extraction of higher than } 80 \% \text { for } \mathrm{Cd}, \mathrm{Cu} \text {, and } \mathrm{Zn} \text {. } \\
\text { Low efficiency for } \mathrm{Pb} \text { (re-precipitate as } \mathrm{PbSO}_{4} \text { ) }\end{array}$ & $\begin{array}{l}\text { Krebs et al. } \\
(2001,1997)\end{array}$ \\
\hline \multirow[t]{3}{*}{$\begin{array}{l}\text { Electro- } \\
\text { chemical }\end{array}$} & APC & $\begin{array}{l}\text { Assess the electrodialytic remediation for the } \\
\text { removal of } \mathrm{Zn}, \mathrm{Pb}, \mathrm{Cu} \text { and } \mathrm{Cd}\end{array}$ & $\begin{array}{l}\text { Experimental results showed low efficiencies for the } \\
\text { electrodialytic removal of } \mathrm{Zn}, \mathrm{Pb}, \mathrm{Cu} \text { and } \mathrm{Cd}\end{array}$ & $\begin{array}{l}\text { Ferreira } \\
\text { et al. (2005) }\end{array}$ \\
\hline & ESP & $\begin{array}{l}\text { Utilization of assisting agents (ammonium citrate) } \\
\text { for electrodialytic removal of metals }\end{array}$ & $\begin{array}{l}\text { The best compromise for removal of } \mathrm{Cd}, \mathrm{Pb}, \mathrm{Zn}, \mathrm{Cu} \text { and } \mathrm{Cr} \\
\text { was obtained with the } 0.25 \mathrm{M} \text { ammonium citrate } / 1.25 \% \mathrm{NH}_{3} \\
\text { solution. Up to } 86 \% \mathrm{Cd}, 20 \% \mathrm{~Pb}, 62 \% \mathrm{Zn}, 81 \% \mathrm{Cu} \text { and } 44 \% \\
\text { Cr was removed in electrodialytic remediation and the time } \\
\text { of the experiments was 5-70 days }\end{array}$ & $\begin{array}{l}\text { Pedersen } \\
(2002) \\
\text { Pedersen } \\
\text { et al. (2005) }\end{array}$ \\
\hline & $\mathrm{CA}$ & $\begin{array}{l}\text { Heavy metal extractability }(\mathrm{Pb}, \mathrm{Cd}, \mathrm{Cr}, \mathrm{Cu}) \text { and } \\
\text { subsequent recovery }\end{array}$ & $\begin{array}{l}\text { Solvent extraction and electrolytic recovery is technically } \\
\text { feasible }\end{array}$ & $\begin{array}{l}\text { Yang and } \\
\text { Tsai (1998) }\end{array}$ \\
\hline \multirow[t]{4}{*}{ Thermal } & ESP & $\begin{array}{l}\text { Recycling heavy metals by fractionated } \\
\text { condensation }\end{array}$ & $\begin{array}{l}\text { Heavy metals are volatile in the presence of } \mathrm{HCl}(\mathrm{g}) \text {, and } \\
\text { condensation is a promising method }\end{array}$ & $\begin{array}{l}\text { Auer et al. } \\
(1999)\end{array}$ \\
\hline & & $\begin{array}{l}\text { Analysis of the evaporation of heavy metals } \\
\text { through heat treatment }\end{array}$ & $\begin{array}{l}\text { Evaporation rates higher than } 98 \% \text { are obtained for } \mathrm{Pb}, \mathrm{Cd} \\
\text { and } \mathrm{Cu} \text { at } 1000-1100^{\circ} \mathrm{C} \text {, decreasing above this temperature }\end{array}$ & $\begin{array}{l}\text { Jakob et al. } \\
(1995)\end{array}$ \\
\hline & & $\begin{array}{l}\text { Influence of chlorides on evaporation rates of } \\
\text { heavy metals }\end{array}$ & $\begin{array}{l}\text { The amounts evaporated as well as the rates of evaporation } \\
\text { are strongly influenced by chlorides }\end{array}$ & $\begin{array}{l}\text { Jakob et al. } \\
\text { (1996) }\end{array}$ \\
\hline & & Analysis of the $\mathrm{ZnCl}_{2}$ evaporation & $\begin{array}{l}\text { Several factors have influence on the degree of } \mathrm{Zn} \\
\text { evaporation (composition, surface area) }\end{array}$ & $\begin{array}{l}\text { Stucki and } \\
\text { Jakob } \\
(1997)\end{array}$ \\
\hline
\end{tabular}


A summary of the recent literature concerning separation processes for the treatment of ESP, FF, CA and APC residues produced during MSW incineration is presented in Table 4. The information indicated in this table was structured according to the separation process, type of residue analysed, the objective of the study and the main conclusion(s) drawn by the author(s). From these studies, it can be concluded that several separation techniques were tested for APC residues, having been considered technically feasible. When the cost of the treatment is not an important issue, a sustainable solution can be found by using separation processes. In fact, some methodologies are very effective at removing the hazardous substances, and consequently non-hazardous materials can be obtained. On the other hand, separation processes may also be regarded as a first step for further treatments, promoting recycling strategies. In addition to the processes included in Table 4 , several separation treatments have been patented (Kuramochi et al., 2005; Mercier et al., 2002; Sawell and Hetherington, 2001; Carre and Templier, 1995; Kauser and LaMastro, 1991).

In our opinion, the removal of the soluble salts is crucial or even almost inevitable for sustainable treatment or the use of waste as secondary material.

\subsection{Solidification/stabilization $(S / S)$}

The solidification/stabilization processes (S/S), Fig. 5, are those that use additives or binders in order to immobilize physically and/or chemically hazardous components initially present in waste (Wiles, 1996). Solidification involves the transformation of a liquid or sludge into solids, and may not lead to a chemical interaction of the constituent of concern with the solidifying agent. The process reduces the mobility of the contaminants in the treated material through encapsulation, as a consequence of the reduced surface area and low permeability. On the other hand, the main goal of stabilization is to convert the contaminants into less soluble or less toxic forms, with or without solidification. In practice, the best approach to $\mathrm{S} / \mathrm{S}$ technology involves firstly chemical stabilization and then solidification of the waste; inorganic materials, such as cements or pozzolanic materials, are the most common binders. S/S methods consist of mixing the binders with the waste and water, and sometimes with chemical additives (e.g., sodium silicate or soluble phosphates). The quantities involved are optimized as a function of the performance required for the final product (leaching behaviour, mechanical strength, setting time, etc.), which may be either solid massive (monolithic) or granular. When Portland cement or similar binders are employed, the product is monolithic and a significant increase in weight and volume may occur, which affects shipping and landfill costs. Moreover, it should be pointed out that, although $\mathrm{S} / \mathrm{S}$ processes are one of the most used methods, they are not effective for treating soluble salts. Therefore, since APC residues contain high levels of salts, the leaching of these salts from the S/S matrix over time is likely to result in poor performance. The subsequent loss of physical properties and durability of the treated product may lead to an increase in metals released. In general, irrespective of the S/ $\mathrm{S}$ method used, the treatment is carried out in order to comply with landfill criteria. Huang and Chu (2003) point out that bag filter precipitator residues and scrubber residues have cement-like compositions, and therefore can be easily immobilized by cement.

Conner and Hoeffner (1998a,b) present a synopsis of the history of the S/S technology and a critical review of these methods. The schema in Figs. 6 and 7 were prepared on the basis of their work, and we can conclude that S/S technology

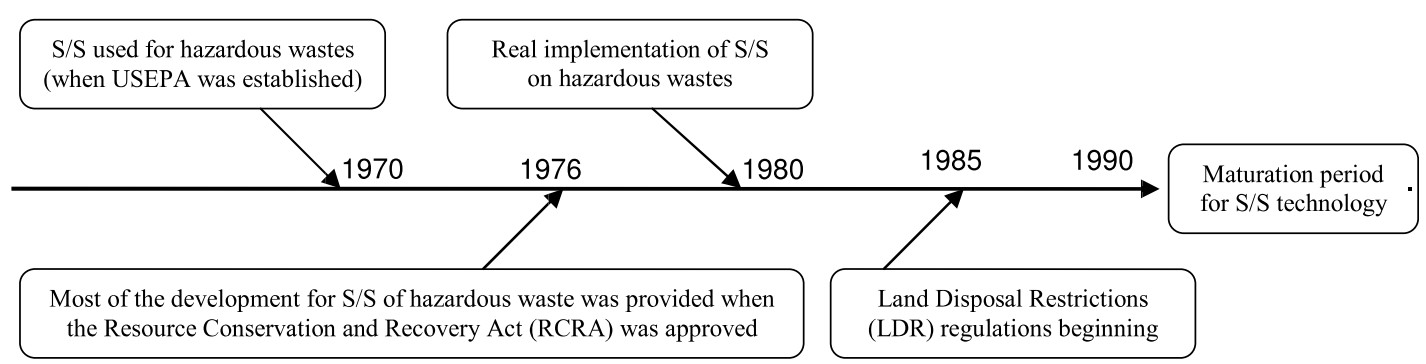

Fig. 6. Summary of the history of S/S technology (based on Conner and Hoeffner, 1998a).

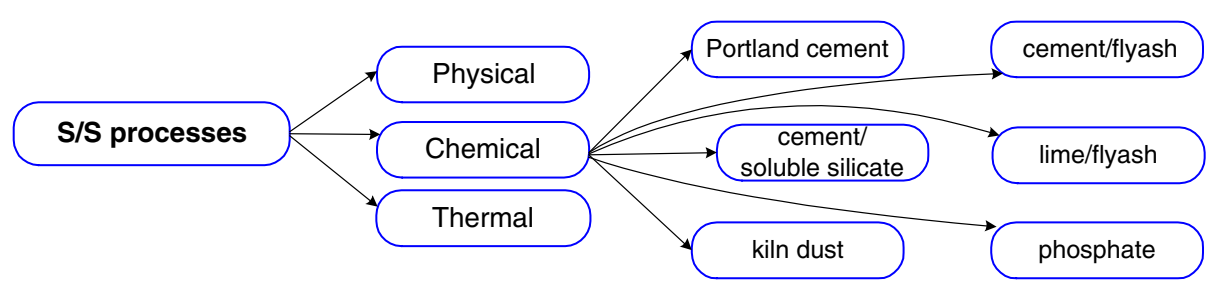

Fig. 7. Overview of the S/S processes (based on Conner and Hoeffner, 1998b). 
Table 5

Treatment of APC residues by S/S processes - chemical stabilization (Group A)

\begin{tabular}{lll}
\hline S/S & Residue & Objective /methodology \\
\hline Soluble phosphate-treatment & FF & $\begin{array}{l}\text { Immobilization of heavy metals using } \\
\text { soluble phosphates combined with "high } \\
\text { specific surface area lime" }\end{array}$
\end{tabular}

Stabilization with soluble phosphates

DS

Stabilization of heavy metal by using soluble phosphate at a dosage of $1.2 \mathrm{~mol}$ of $\mathrm{H}_{3} \mathrm{PO}_{4} / \mathrm{kg}$ of residue. The chemical additive is mixed with the waste during $10 \mathrm{~min}$ at a $L / S$ ratio of 0.4

Chemical stabilization $\left(\mathrm{H}_{3} \mathrm{PO}_{4}\right)$ and calcination at $900^{\circ} \mathrm{C}$

APC

Study of chemical and thermal treatments for APC residues. The procedure consists of mixing $1 \mathrm{~kg}$ of waste with $2 \mathrm{~L}$ of water, $20 \mathrm{~g}$ of $\mathrm{Ca}(\mathrm{OH})_{2}$ and $60 \mathrm{~g}$ of $\mathrm{H}_{3} \mathrm{PO}_{4}$. The suspension was stirred for $30 \mathrm{~min}$, and after filtering and drying at $60^{\circ} \mathrm{C}$, the calcination in air at $900^{\circ} \mathrm{C}$ of the solid was performed

Chemical stabilization with chelating agent, phosphate and ferrite

APC Evaluation of treatments with a chelating agent, phosphate treatment, ferrite treatment. Analysis of leaching behaviour, the total availability

Stabilization with chelating agent

Stabilization with phosphate

SDS

Fly ashes are mixed with chelating agents

APC Monitoring the stabilization of fly ash by phosphatation. The treatment consist in three steps: removing the salts (chlorides, sulphates) by dissolution at basic $\mathrm{pH}$, phosphation of the residue to trap metals, and its calcination to destroy dioxin-like compounds

Stabilization with ferrous sulphate solution and oxidation

APC Treatment of the residue with a ferrous

FA sulphate solution and subsequent oxidation of the suspension. The suspension was spread on a dedicated landfill which drains by gravity through the drainage system of the landfill

Stabilization with phosphates APC Immobilization of lead and zinc in APC residues by using soluble phosphates

Stabilization with $\mathrm{FeSO}_{4}$ and $\mathrm{Fe}_{2}\left(\mathrm{SO}_{4}\right)_{3}$ solutions

Stabilization with colloidal aluminate oxide

APC

Study the effectiveness of mixing $\mathrm{FeSO}_{4}$ and $\mathrm{Fe}_{2}\left(\mathrm{SO}_{4}\right)_{3}$ solutions with APC residues in order to stabilize heavy metals

Stabilize lead by using colloidal aluminate oxide (CAO)
Conclusion

The "high specific surface area lime" allows to reduce to about $1 / 2$ of the conventional lime injection rate, and the treatment costs by soluble phosphate can be remarkably reduced

The treatment with soluble phosphate is an effective stabilization method for divalent heavy metals $(\mathrm{Pb}, \mathrm{Zn})$, due to precipitation of metal phosphates rather than adsorption processes. The products formed are crystalline and amorphous calcium phosphates, tertiary metal phosphates and apatite family minerals Chemical treatment reduces heavy metal ion solubility. Thermal treatment affects also significantly the solubility of metal ions with respect to chelating ligands, due to the incorporation of the metals in a calcium phosphate matrix. The thermal treatments at $900{ }^{\circ} \mathrm{C}$ avoid metal loss by evaporation and contribute to apatite crystallization

The treatment using a chelating agent is based on complexation of metals with an organic sulphide and a high reducing capacity and strong retention for metals is observed over a wide $\mathrm{pH}$ range. The treatment with phosphate showed a significant decrease in availability, mainly for $\mathrm{Pb}$. The treatment with ferrite showed an increased physical retention Chelating agents are more efficient than inorganic chemicals (sodium sulfide and lime) Carbonation and partial immobilization of $\mathrm{Pb}$ and $\mathrm{Zn}$ by calcite neoformed occur during washing. Precipitation of calcium phosphates traps $\mathrm{Pb}$ and $\mathrm{Zn}$ during phosphation by destruction of the neoformed calcite. The calcination allows the stabilization of $\mathrm{Pb}$ and $\mathrm{Zn}$ by recrystallization of the mineral phases The wastewater from the process, collected through the drainage system, contained large concentrations of salts but low concentrations of trace metals. The concentrations of trace metals were reduced by up to four orders of magnitude. The effect on oxyanions (e.g. Cr) is very low With cement as well as with phosphates a reduction in $\mathrm{Pb}$ and $\mathrm{Zn}$ leaching was observed. However, with soluble phosphates, the $\mathrm{Pb}$ leaching was lower than with cement

The solution reacted with the scrubber ash to form $\mathrm{Ca}_{4} \mathrm{Fe}_{9} \mathrm{O}_{17}$, which coated the surface of ash particles, and therefore the heavy metal releasing is decreased

CAO reveals a high reduction ratio for the leachability of $\mathrm{Pb}$ of $94.8 \%$ when compared with other commercial fixation agents. An immobilization mechanism is proposed, with the critical process being the formation of the $\mathrm{Al}(\mathrm{OH})_{3} / \mathrm{Pb}(\mathrm{OH})_{2}$ crystals

Ferrihydrite was formed initially but converted upon thermal treatment into more stable and crystalline compounds (maghemite and hematite). However, the overall effect of the Ferrox process followed by thermal treatment is an initially more contaminated leachate but the

product obtained is more stable in the long term
Reference

Uchida et al. (1996)

Eighmy et al. (1997)

Iretskaya et al. (1999)

Mizutani et al. (2000)

Jianguo et al. (2004)

Piantone et al. (2003)

Lundtorp et al. (2002, 2003)

Geysen et al. (2004a)

Hu (2005)

Huang and

Lo (2004)

Sorensen et al. (2000)

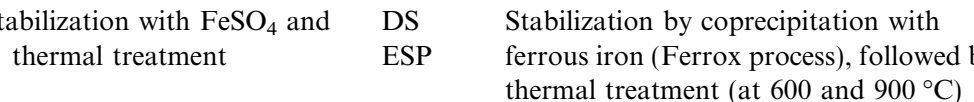

$\begin{array}{lll}\text { tabilization with } \mathrm{FeSO}_{4} \text { and } & \text { DS } & \begin{array}{l}\text { Stabilization by coprecipitation with } \\ \text { ferrous iron (Ferrox process), followed by } \\ \text { thermal treatment (at } 600 \text { and } 900^{\circ} \mathrm{C} \text { ) }\end{array}\end{array}$

$\begin{array}{lll}\text { tabilization with } \mathrm{FeSO}_{4} \text { and } & \text { DS } & \begin{array}{l}\text { Stabilization by coprecipitation with } \\ \text { thermal treatment }\end{array} \\ \text { ESP } & \begin{array}{l}\text { ferrous iron (Ferrox process), followed by } \\ \text { thermal treatment (at } 600 \text { and } 900^{\circ} \mathrm{C} \text { ) }\end{array}\end{array}$

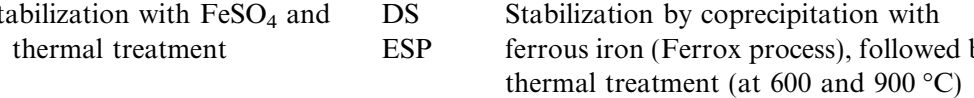


is at present in the maturing phase (Fig. 6), with a number of research projects aiming at optimizing the process. Fig. 7 shows that $\mathrm{S} / \mathrm{S}$ processes can be classified into physical, thermal and chemical processes. $\mathrm{S} / \mathrm{S}$ treatments that use chemical fixation/interaction may employ some possible combinations, the most common being those that use Portland cement, cement and fly ash from coal, cement and soluble silicates, lime and fly ash from coal, kiln dust, and soluble phosphates.

On the subject of cement solidification and stabilization, Glasser $(1994,1997)$ discusses the most important issues to be considered in this technology. Also related with these processes, Gougar et al. (1996) present a review concerning ettringite and calcium silicate hydrate $(\mathrm{CSH})$ phases from Portland cement for waste ion immobilization, where the interaction with priority metallic pollutants $(\mathrm{Cr}, \mathrm{Pb}, \mathrm{Ba}$, $\mathrm{Se}, \mathrm{Zn}, \mathrm{Ag}, \mathrm{Hg}$, As and $\mathrm{Cd}$ ) was analyzed. Ettringite may interact with a number of these ions in both the columnar and channel sections of the crystal structure. Immobilization mechanisms for $\mathrm{CSH}$ include sorption, phase mixing and substitution. For heavy metals, the main factors in the immobilization process are $\mathrm{pH}$, chemical speciation of metal, and redox potential control. Regarding organic compounds, immobilization can occur through reactions that destroy or alter organic structures or through physical processes such as adsorption and encapsulation.

An overview of the large body of recent research in the field of $\mathrm{S} / \mathrm{S}$ methods applied to incineration residues (fly ashes and/or APC residues) is indicated in Tables 5-8. In addition, many more processes can be found in patents (Derie, 2000; Cartier et al., 1998; Sasae et al., 1996; Nicholson, 1978).
An analysis of the most frequently studied methodologies suggests that four groups can be formed:

(1) Chemical stabilization (Group A) - with the addition of chemical compounds aiming at fixing the toxic species, Table 5;

(2) Chemical fixation and solidification with binders (Group B) - in order to take advantage of Group A with those properties obtained when binders are used, Table 6;

(3) Solidification with binders (Group C) - mainly using Portland cement of different types, involving the replacement of some amount of cement by other materials with a similar effect but lower price, Table 7 ;

(4) Miscellaneous (Group D) - all other strategies (polymer-concrete, carbonation, aging, etc.), Table 8.

Van de Laar et al. (1994) present a study resulting from a project that involved five companies with different treatment strategies. The methods entail processes of 1,2 or 3 steps, with or without chemical additives (silicates or others), with or without cement or thermal treatment. This study revealed that with the exception of chlorides, the immobilization of most toxic elements is possible through $\mathrm{S} / \mathrm{S}$ processes.

From the literature, it is clear that nowadays the most dynamic research area is in the field of solidification with binders, using in particular Portland cement. In practice, at the industrial level in Europe, this is indeed the most important method for treatment of APC residues. It should be emphasized that the main disadvantages of

Table 6

Treatment of APC residues by S/S processes - chemical fixation and solidification with binders (Group B)

\begin{tabular}{|c|c|c|c|c|}
\hline $\mathrm{S} / \mathrm{S}$ & Residue & Objective/methodology & Conclusion & Reference \\
\hline $\begin{array}{l}\text { Cement and } \\
\text { stabilizing } \\
\text { agents }\end{array}$ & APC & $\begin{array}{l}\text { Comparison of treatments with commercially } \\
\text { stabilizing agents and cement. It is tested a solidifying } \\
\text { powder (SFPA -mixture of inorganic agents). The } \\
\text { residue is mixed with SFPA and pelletized in spheres }\end{array}$ & $\begin{array}{l}\text { By using SFPA (Sumitomo Fine Powder Agent) the } \\
\text { heavy metals can be immobilized. No toxic gases are } \\
\text { formed during the chemical treatment }\end{array}$ & $\begin{array}{l}\text { Kawakami } \\
\text { et al. } \\
(1996)\end{array}$ \\
\hline $\begin{array}{l}\text { Cement, } \\
\mathrm{Al}_{2}\left(\mathrm{SO}_{4}\right)_{3}, \\
\mathrm{Ca}(\mathrm{OH})_{2} \text {, coal } \\
\text { fly ash }\end{array}$ & ESP & $\begin{array}{l}\text { Treatment of fly ash for minimizing the geo- } \\
\text { environment impact }\end{array}$ & $\begin{array}{l}\text { The stabilized residue with cement and coal ash can } \\
\text { be used for embankments }\end{array}$ & $\begin{array}{l}\text { Kamon } \\
\text { et al. } \\
(2000)\end{array}$ \\
\hline
\end{tabular}


Table 7

Treatment of APC residues by S/S processes - solidification with binders (Group C)

\begin{tabular}{lll}
\hline$S / S$ & Residue & Objective/methodology \\
\hline $\begin{array}{l}\text { Reactive calcium } \\
\text { aluminates }\end{array}$ & ESP & $\begin{array}{l}\text { Analysis of the hydration reactions taking place } \\
\text { when the waste is stabilized and immobilized by } \\
\text { reactive calcium aluminates. The new phases } \\
\text { formed and the fixation mechanisms of } \mathrm{SO}_{4}^{2-}, \mathrm{Cl}^{-} \\
\text {and heavy metals were investigated }\end{array}$
\end{tabular}

Portland cement type I; blast furnace slag; superplasticizer

ESP

Statistical analysis of physicochemical properties of monoliths solidified with ASTM Type I portland cement alone; a partial replacement of Type I portland cement by powdered waterquenched blast furnace slag, by addition of Polymer SP (a superplasticizer) to cement, and by concurrent replacement of cement by slag and addition of Polymer SP

Portland cement (ASTM type I)

CA+SDS Study of the effects of the chelate EDTA addition or on properties of cement-solidified municipal $\mathrm{DS}+\mathrm{FF} \quad$ incinerator fly ash

\section{Washing + Portland
Cement ASTM Type III}

Fly Ash

Optimization of the $\mathrm{S} / \mathrm{S}$ process of cement based matrices. The washing process comprehends two stages (water at a liquid/solid ratio of 25 , for $15 \mathrm{~min}$ for each stage). After each mixing step, the fly ash was filtered and dried in an oven at $105^{\circ} \mathrm{C}$

Pozzolanic Cement ESP type IV/A 42.5

Analysis of the influence of the residue on the S/S processes with cement paste, in particular of the hydration behaviour

The hydraulic binder is pozzolanic cement formed by mixing ordinary portland cement (OPC) and an Italian natural pozzolan

$\begin{array}{cl}\begin{array}{c}\text { Portland cement } \\ \text { (type I) }\end{array} & \text { FA } \\ & \text { APC }\end{array}$

FA

\section{Treatment through $\mathrm{S} / \mathrm{S}$, and in particular study the durability of matrices as a function of} carbonation

$\begin{array}{cll}\begin{array}{c}\text { Ordinary Portland } \\ \text { cement class }\end{array} & \text { ESP } & \text { APC (FF; } \\ \text { 42.5R (OPC) } & \text { ESP) } & \text { composition of municipal solid waste incineration } \\ \text { (MSWI) FA and its effect on cement hydration }\end{array}$

Conclusion Reference

The reactive calcium aluminates allow to fix heavy metals, $\mathrm{SO}_{4}^{2-}$ and $\mathrm{Cl}^{-}$in hydration products. The formation of ettringite and Friedel's salt leads to fixation of toxic anions and cations. These aluminates can be the first step for solidification and fixation and can be followed by the addition of other binders

The results of analysis of variance showed that the weight ratio of water-to-binder(s) is the most important parameter for the compressive strength. The weight ratio of ESP to binder(s) is also important to the values of unconfined compressive strength, leaching toxicity, and acid neutralization capacity of some solidified specimens EDTA does not have a significant effect in solidification process with cement. The Portland cement alone is capable of stabilizing the heavy metals contained on APC residues. The use of EDTA alone only slightly reduces the leaching of the residue Washing treatment is a suitable means of improving the setting time of ash-cement mixtures. For untreated fly ash the quantities used should not be higher than $35 \%$ by weight, while after washing up to $75 \%-90 \%$ can be treated. A reduction of the $\mathrm{S} / \mathrm{S}$ treatment cost by about $50 \%-63 \%$ can be achieved through pre-washing

The ESP provokes in the first curing period the slowing of hydration reactions of calcium silicates of cement and formation of gypsum and ettringite. With the increase of the fly ash on the mixture there is a lengthening of the period in which the hydration reactions of the calcium silicates are inhibited

APC residues showed a rapid setting velocity in comparison with FA residues. Leaching test showed that heavy metals $(\mathrm{Zn}, \mathrm{Pb}, \mathrm{Cd})$ and sulphates are immobilised within the paste, whereas chlorides are partially retained. The carbonation process increases the leachability of $\mathrm{SO}_{4}^{2-}, \mathrm{Zn}, \mathrm{Cr}$

The setting and hardening are strongly dependent on the technology used for flue gas treatment downstream of the combustion chamber. The mechanical properties of the stabilized residue could not be predicted based on the effect of heavy metals and anions
Auer et al. (1995)

Yang and Chen (1996)

Yang et al (1998)

Mangialardi et al. (1999)

Ubbrìaco and Calabrese (1998, 2000)

Alba et al. (2001)

Polettini et al. (2001) treatment with cement are related with the significant increase in the mass (almost double) disposed of, the low retention of salts, which may leach out in the short term, the possible release of heavy metals in the medium to long term, and finally the problem of the monolith formed at the landfill site that will hardly ever be used again. The main advantages come from the fact that this technology is well established and low cost. To our mind, it is advisable to remove the salts before adding the binders, whenever possible. The use of chemical additives may also be appropriate for solving some specific problems, such as when the residue contains high quantities of a specific toxic element.

\subsection{Thermal methods}

Some thermal methods have also been considered for APC residues in order to obtain a material that is environmentally stable. In fact, these processes may result in a significant reduction in waste volume, requiring less space when the option is landfilling. On the other hand, the leaching processes are strongly reduced since the porosity of the 
Table 8

Treatment of APC residues by S/S processes - miscellaneous (Group D)

\begin{tabular}{|c|c|c|c|c|}
\hline$S / S$ & Residue & Objective/methodology & Conclusion & Reference \\
\hline $\begin{array}{l}\text { Polymers } \\
\text { (LDPE, PS, } \\
\text { PVC) concrete } \\
\text { double } \\
\text { matrices }\end{array}$ & APC & $\begin{array}{l}\mathrm{S} / \mathrm{S} \text { evaluation by using polymers through co- } \\
\text { rotating twin-screw extrusion Retention } \\
\text { properties of the polymers were compared with } \\
\text { the concrete ones and polymer-concrete double } \\
\text { matrices }\end{array}$ & $\begin{array}{l}\text { The retention of pollutants follows the order: } \\
\text { polymer-concrete }>\text { PVC }>\text { LDPE }>\text { two polymer } \\
\text { blends }>\text { three polymer blends }>\text { concrete. This } \\
\text { study shows that plastic waste can be used for fly } \\
\text { ash solidification, being then the cost lower than } \\
\text { by using only cement }\end{array}$ & $\begin{array}{l}\text { Massardier } \\
\text { et al. } \\
(1997)\end{array}$ \\
\hline $\begin{array}{l}\text { Solidification } \\
\text { with water }\end{array}$ & $\begin{array}{l}\mathrm{APC} \\
(\mathrm{ESP}+\mathrm{BF}+\mathrm{DS})\end{array}$ & $\begin{array}{l}\text { Investigation of the solidification with water as a } \\
\text { method of treatment. The influence of the } \\
\text { amount of water, time, and temperature to } \\
\text { mechanical strength of solid material was studied }\end{array}$ & $\begin{array}{l}\text { By adding water to APC residues, cementitious } \\
\text { reaction can be initiated, leading to solidification. } \\
\text { The compressive strength is dependent on the } \\
\text { time and temperature, and on the interaction } \\
\text { between water addition and time. The leaching } \\
\text { processes are not diffusion controlled }\end{array}$ & $\begin{array}{l}\text { Todorovic } \\
\text { et al. } \\
(2003)\end{array}$ \\
\hline Carbonation & $\begin{array}{l}\text { APC } \\
\text { BA }\end{array}$ & $\begin{array}{l}\text { Assess the effect of carbonation on the } \\
\text { demobilization of critical components from the } \\
\text { compacted residues }\end{array}$ & $\begin{array}{l}\text { Carbonation proved to be an ineffective method } \\
\text { for stabilize } \mathrm{Cl}^{-} \text {and } \mathrm{SO}_{4}^{2-} \text {. Carbonation was } \\
\text { more effective in demobilising critical } \\
\text { components in BA than in APC residues } \\
\text { Reducing conditions may contribute to stabilize } \\
\text { of } \mathrm{Cr} \text { and } \mathrm{Se} \text { in these residues }\end{array}$ & $\begin{array}{l}\text { Todorovic } \\
\text { and Ecke } \\
(2006)\end{array}$ \\
\hline Aging & APC & $\begin{array}{l}\text { Study of the effect of water content on the aging } \\
\text { processes, at a liquid to solid ratio }(L / S) \text { of } 0.25 \\
\text { or } 10 \text {, and with or without contact with ambient } \\
\text { air }\end{array}$ & $\begin{array}{l}\text { The releasing of } \mathrm{Pb}, \mathrm{Zn}, \mathrm{Cd}, \mathrm{Hg} \text {, and } \mathrm{Cu} \text { decrease } \\
\text { with age and } \mathrm{Cr} \text { increase. For } L / S=10 \\
\text { controlling step is the dissolution and diffusion of } \\
\mathrm{CO}_{2} \text { in the bulk solution. When } L / S=0.25 \text { the } \\
\text { limiting step is the dissolution of metals from ash } \\
\text { particles }\end{array}$ & $\begin{array}{l}\text { He et al. } \\
(2006)\end{array}$ \\
\hline
\end{tabular}

produced material is very low. Due to the high temperatures used, these methods are very efficient at destroying dioxins, furans and other toxic organic compounds (Sakai and Hiraoka, 2000). In fact, the number of vitrification plants in Japan increased significantly when dioxins had to be taken into account, according to the criteria of specially controlled waste established in 1999 (Jung et al., 2005). The final material has been considered suitable for reuse in practical applications, due to the fact that those thermal processes lead to the incorporation of elements of concern in the glass matrix through chemical bounding and/or encapsulation. In addition to the processes described, the reaction of $\mathrm{CaO}$ (soluble) to $\mathrm{CaO}$ (insoluble) at high temperatures leads to a decrease in the $\mathrm{pH}$ value and therefore to a change in the solubility of heavy metals.

In general, thermal methods can be divided into three groups (IAWG, 1997), Fig. 5:

(1) Sintering - the temperature is increased until the chemical species of interest can achieve a reconfiguration. Usually the temperatures involved in this process are in the range of $900-1000{ }^{\circ} \mathrm{C}$, and a denser product is obtained;

(2) Vitrification - the material is melted with additives (glass precursors) in order to fix the contaminants in the final matrix (alumina-silicates). The temperatures involved are $1100-1500{ }^{\circ} \mathrm{C}$ and the material is cooled to form a single solid phase (amorphous and homogeneous). Since the method is expensive, this treatment is not generalized for APC residues;

(3) Melting (or Fusion) - although the process is similar to vitrification, in this case no additives are used, and the glass formed may not be homogeneous. Therefore, the product obtained can be used as a construction material, for example, as a sub-base in road construction or for pavements (Ecke et al., 2000). Sakai and Hiraoka (2000) divided the melting systems into two groups: fuel-burning melting systems and electric melting systems, and it is possible to subdivide each one further, as indicated in Fig. 8. At present, it is not clear which system is the best. In general, for large incinerators with a power generation facility, the electric melting systems may have advantages, since they can use the recovered electric power. In the case of small incinerators without power generation, the fuel-burning melting system may be preferable.

Kinto (1996) points out that, when the APC residues have significant quantities of unreacted lime, the melting process can be difficult because of the high flow point. It is important to note that during these thermal treatments, new fly ashes (dust) are produced which contain larger amounts of volatile species such as $\mathrm{Hg}, \mathrm{Cd}, \mathrm{Pb}, \mathrm{S}, \mathrm{Cl}, \mathrm{K}$, $\mathrm{Na}$ and $\mathrm{Zn}$. Those elements may form simple salts (e.g., 
$\mathrm{PbCl}_{2}, \mathrm{ZnSO}_{4}$ ), and are then highly leachable. Therefore, these new residues are also hazardous, and require further treatment. Eighmy et al. (1998) showed that an efficient method for those hazardous ashes could be treatment with soluble phosphates, as that process is particularly efficient for $\mathrm{Cd}, \mathrm{Cu}, \mathrm{Pb}$ and $\mathrm{Zn}$. The main phases formed are minerals such as $\mathrm{Zn}_{3}(\mathrm{PO} 4)_{2}$ and apatites such as $\mathrm{Pb}_{5}\left(\mathrm{PO}_{4}\right)_{3} \mathrm{Cl}$. In fact, the use of soluble phosphates effectively transforms soluble metal salts into insoluble metal phosphate phases. Some of the separation techniques referred to earlier may also be applied to these ashes.

Tables 9-11 provide an overview of the recent literature in the field of thermal treatments (melting, vitrification and sintering) applied to incineration residues (fly ashes and/or APC residues). Moreover, many patented processes are well established for thermally treating the residues under analysis (Albus and Santora, 2003; Mechtersheimer,
2001; Swithenbank, 2000; Mechtersheimer and Wieckert, 1998; John, 1995; Harada et al., 1992).

The main conclusion is that, through these thermal treatments, an environmentally stable material can be produced for which applications may be easily found, including use as secondary raw material. The most important drawback of this process is the high cost that may be involved, due to the high power input required. It is important to stress that thermal processes constitute one of the best methods of destroying highly toxic trace organic compounds (e.g., dioxins and furans).

\subsection{Combined methods}

A possible strategy for the treatment of the residues produced during MSW incineration involves the combination of separation methods with $\mathrm{S} / \mathrm{S}$ and/or thermal treatments.

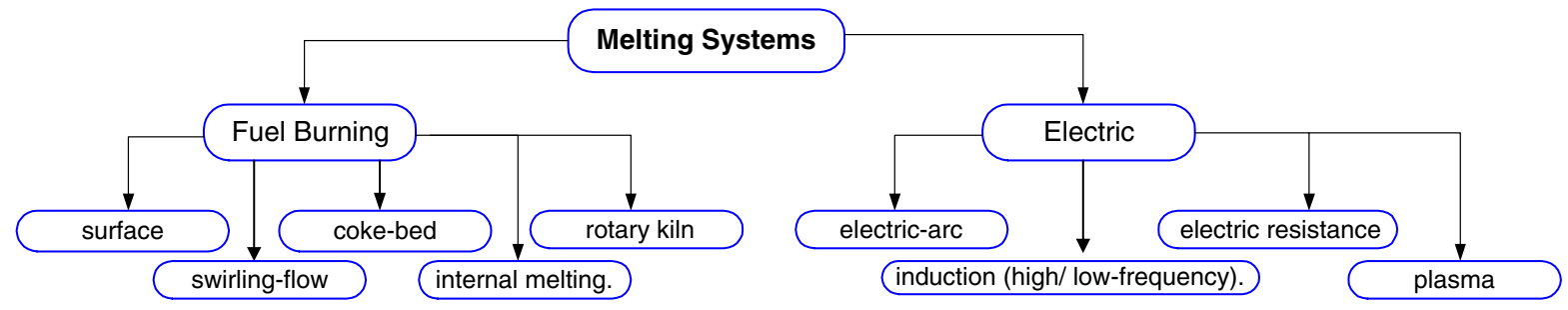

Fig. 8. Classification of melting systems (based on Sakai and Hiraoka, 2000).

Table 9

Treatment of APC residues by thermal (melting) processes

\begin{tabular}{|c|c|c|c|c|}
\hline Thermal & Residue & Objective & Conclusion & Reference \\
\hline $\begin{array}{l}\text { Melting } \\
\quad \text { (rotating } \\
\text { surface } \\
\text { melting } \\
\text { furnace) }\end{array}$ & $\begin{array}{l}\text { FA } \\
\text { (ESP) }\end{array}$ & Ash melting treatment & $\begin{array}{l}\text { Fly ash melts without any additive at a temperature } \\
\text { of } 1280-1330{ }^{\circ} \mathrm{C} \text {, being } 88 \% \text { of the residue } \\
\text { converted to slag and } 12 \% \text { in dust (new fly ash). } \\
\text { From the } 10 \mathrm{ng} \text { TEQ/g of dioxins present in the } \\
\text { residue, } 99,98 \% \text { are destroyed. The produced slag is } \\
\text { safe for the environment and adequate to be used } \\
\text { for ceramics }\end{array}$ & $\begin{array}{l}\text { Abe et al. } \\
\text { (1996) }\end{array}$ \\
\hline Melting & FA & Overview of the melting technologies in Japan & $\begin{array}{l}\text { Stable and non-toxic materials were obtained } \\
\text { through melting processes, and the melted slag can } \\
\text { be used as a resource. The PCDDs/PCDFs in } \\
\text { residues are decomposed at the operating } \\
\text { temperatures and the volatile heavy metals are } \\
\text { concentrated in the fly ash of the melting process }\end{array}$ & $\begin{array}{l}\text { Sakai and } \\
\text { Hiraoka } \\
(2000)\end{array}$ \\
\hline $\begin{array}{l}\text { Melting } \\
\text { (several } \\
\text { types of } \\
\text { processes) }\end{array}$ & $\begin{array}{l}\text { FA } \\
\text { BA }\end{array}$ & $\begin{array}{l}\text { Study of the metal behaviour in ash-melting and } \\
\text { municipal solid waste (MSW) gasification-melting } \\
\text { facilities }\end{array}$ & $\begin{array}{l}\text { The behaviour of metals is mainly determined by its } \\
\text { volatility. The chlorine content in feedstock can } \\
\text { have a significant effect on } \mathrm{Cu} \text { but not on } \mathrm{Pb} \text {. The } \\
\text { behaviour of } \mathrm{Zn} \text { is influenced by the oxidizing } \\
\text { condition in the furnace }\end{array}$ & $\begin{array}{l}\text { Jung et al. } \\
(2005)\end{array}$ \\
\hline
\end{tabular}


Some experimental studies have shown that some synergies can be obtained by taking advantage of each of the selected methods. In Table 12 some examples are given of such studies found in the literature. The main aspects that should be considered are, firstly, the fact that removing the soluble salts is advantageous and, secondly, that chemical stabilization can improve the results obtained through $\mathrm{S} / \mathrm{S}$ or thermal methods, which generally aim to fix heavy metals.

\section{Possible applications}

Even though the treatments described above can be very effective at fixing the various potential toxic components of APC residues, another question is raised, namely what to do with the treated residue. Naturally, it would be better to find a practical application than merely dump the material in a landfill site. To obtain a valuable product (according to Fig. 2), two strategies may be applied: either treating the residue in order to improve some of its characteristics and then producing a final product, or obtaining the final product directly.

According to Ferreira et al. (2003), nine potential applications were identified in the literature for incineration residues, which can be grouped into four main categories: construction materials (cement, concrete, ceramics, glass and glass-ceramics); geotechnical applications (road pavement, embankments); agriculture (soil amendment), and miscellaneous (sorbent, sludge conditioning). The authors conclude that there is no evidence for selecting one particular application above the rest. On the other hand, although pre-treatment of the residue may increase the cost

Table 10

Treatment of APC residues by thermal (vitrification) processes

\begin{tabular}{lll}
\hline Thermal & Residue & Objective \\
\hline Vitrification & ESP & $\begin{array}{l}\text { Analysis of the vitrification process with plasma. In } \\
\text { some cases, the addition of silicates and fusing agents) } \\
\text { were used }\end{array}$
\end{tabular}

Vitrification FF Demonstration of the vitrification of fly ash by swirling-flow furnace

Vitrification $\quad$ FA $\quad$ Metal recovery from fly ash generated from BA vitrification processes (at $1350^{\circ} \mathrm{C}$ ). The process consists of pre-treatment, leaching, sulfurization and waste water treatment

Vitrification FA Studies in a pilot plant of vitrification with plasma in order to establish if it is possible to produce a slag that comply with the Dutch regulation for building materials

Vitrification FA Study of the influence of composition variations of FA on the degree and kinetics of the vitrification and crystallization in the vitrified material

Vitrification ESP Vitrification of ESP at $1500^{\circ} \mathrm{C}$ during $30 \mathrm{~min}$ by adding $5 \%$ of $\mathrm{SiO}_{2}$

Vitrification FA Analysis of the metal behaviour during vitrification of incinerator ash in a coke bed furnace. Incinerator ash, coke, and lime were mixed at a ratio of 10:2.5:1, and melted at $1600^{\circ} \mathrm{C}$

Vitrification APC Convert (at $1450^{\circ} \mathrm{C}$ for $1.5 \mathrm{~h}$ ) a residue into a useful BA product, such as a material for construction
Reference

The vitrification with a plasma technology is adequate for ESP from MSW. The obtained slags are inert and the heavy metals are fixed in the silicate matrix

The treatment is effective on reducing the volume, detoxification and stabilization of FF. A new technique for improving the quality of the slag and heavy metals recovery was developed Heavy metals $(\mathrm{Pb}, \mathrm{Zn}, \mathrm{Cd})$ are concentrated into vitrification FA. Almost $100 \%$ of toxic heavy metals in vitrification FA can be recovered by chemical treatment and a detoxified FA is obtained

The VITROARC ${ }^{\circledR}$ process produces a slag material that complies with category I for almost all elements. In most cases well below the limit value. The slag is also tested according to German, Austrian and Swiss regulations and fulfils for disposal as inert material The composition of FA is very important on the degree and kinetics of the process of vitrification. The vitrification increases when the alkali content increases and as the silicon content decrease. Gehelenite can crystallize in high quantities giving a rock-like appearance

The glass formed has a Vickers hardness of 4000$5000 \mathrm{MPa}$, bending strength of $60-90 \mathrm{MPa}$, and a significant leaching resistance. Therefore, vitrification is an effective treatment method Vitrification proved to be a useful technology for disposal of MSW incinerator ash. Metals with low boiling points ( $\mathrm{As}, \mathrm{Cd}, \mathrm{Hg}, \mathrm{Pb}, \mathrm{Zn}$ ) are volatilized and adsorbed in the fly ash, allowing safe reuse and recovery of metals in those fly ashes By increasing the bottom ash or cullet amounts added to the fly ash, the specimen basicity is decreased, leading to a more amorphous glassy matrix. The vitrification allows a volume reduction over $50 \%$, and the slags have small porosity, low water absorption, high compressive strengths and are in compliance with the regulatory limits
Mugica et al. (1995)

Ito (1996)

Izumikawa (1996)

Haugsten and Gustavson (2000)

Frugier et al. (2002)

Park and Heo (2002a)

Kuo et al. (2004)

Li et al. (2003b) 
Table 11

Treatment of APC residues by thermal (sintering) processes

\begin{tabular}{|c|c|c|c|c|}
\hline Thermal & Residue & Objective & Conclusion & Reference \\
\hline $\begin{array}{l}\text { Sintering/ } \\
\text { Vitrification }\end{array}$ & ESP & $\begin{array}{l}\text { Study of the binding of heavy metals in thermally treated } \\
\text { ESP residues. Several temperatures were tested }(400,600 \text {, } \\
\left.800,1000 \text { and } 1400^{\circ} \mathrm{C}\right) \text { for two hours in air }\end{array}$ & $\begin{array}{l}\text { Thermal treatment leads to inertization for } \mathrm{Zn}, \mathrm{Cd}, \mathrm{Pb} \text {, } \\
\mathrm{Cu} \text {, with the exception of } \mathrm{Cr} \text { and Ni. Only for } \mathrm{Cu} \\
\text { vitrification }\left(1400^{\circ} \mathrm{C}\right) \text { reveals higher inertization than } \\
\text { sintering. The enthalpy of the solid/liquid transition is } \\
\text { the decisive factor for choosing the thermal treatment, } \\
\text { and sintering at high temperatures could be better than } \\
\text { vitrification }\end{array}$ & $\begin{array}{l}\text { Wunsch } \\
\text { et al. } \\
(1996)\end{array}$ \\
\hline Sintering & $\mathrm{CA}$ & $\begin{array}{l}\text { Thermo-treatment of the residue for obtaining } \\
\text { aggregates. The temperatures tested were from } 400 \text { to } \\
1000^{\circ} \mathrm{C} \text {, during } 1-4 \mathrm{~h}\end{array}$ & $\begin{array}{l}\text { The sintering process provides an effective alternative for } \\
\text { the treatment and recycling of MSWI fly ash. The } \\
\text { compressive strength of cylinder sintered at } 800{ }^{\circ} \mathrm{C} \text { for } \\
\text { more than } 0.5 \mathrm{~h} \text {, was greater than } 68,5 \mathrm{MPa} \text {. The } \mathrm{Cr} \text { can } \\
\text { be converted in more extractable compounds after } \\
\text { thermal treatment. The heavy metals released by leaching } \\
\text { tests were in compliance with the current thresholds of } \\
\text { legislation }\end{array}$ & $\begin{array}{l}\text { Wang } \\
\text { et al. } \\
(2002)\end{array}$ \\
\hline Sintering & ESP & $\begin{array}{l}\text { Study of the } \mathrm{Cr} \text { behaviour during thermal treatment. A } \\
\text { mass of } 0.5 \mathrm{~g} \text { was preheated in a muffle furnace at } \\
990 \pm 10^{\circ} \mathrm{C} \text { for } 1 \mathrm{~h}\end{array}$ & $\begin{array}{l}\text { Thermal treatment of fly ash was used to remove volatile } \\
\text { metals such as } \mathrm{Pb}, \mathrm{Cd} \text { and } \mathrm{Zn} \text {, but not } \mathrm{Cr} \text {. After thermal } \\
\text { treatment at } 990{ }^{\circ} \mathrm{C} \text { for } 1 \mathrm{~h} \text {, the leachable } \mathrm{Cr} \text { was } \\
\text { increased to about } 12 \% \text { of the Cr content. A mechanism } \\
\text { explaining the increased solubilization was proposed }\end{array}$ & $\begin{array}{l}\text { Kirk } \\
\text { et al. } \\
(2002)\end{array}$ \\
\hline Sintering & FA & $\begin{array}{l}\text { Investigate the continuous sintering behaviour of FA in a } \\
\text { rotary kiln and reduce the concentrations of heavy metal } \\
\text { to tolerable value }\end{array}$ & $\begin{array}{l}\text { The sintering treatment in a rotary kiln can be fitted to } \\
\text { incinerator plants and operated continuously. Water- } \\
\text { washing pre-treatment is an effective process for } \\
\text { decreasing both the sintering temperature }\left(700-900{ }^{\circ} \mathrm{C}\right) \\
\text { and time, removing chlorides from FA }\end{array}$ & $\begin{array}{l}\text { Wey et al. } \\
\text { (2006) }\end{array}$ \\
\hline
\end{tabular}

and may create new problems, it is advantageous for most applications. Romero et al. (2001) identify several applications for this waste, mentioning particularly building materials, catalysts, refractories, pozzolanic materials, glasses and glass-ceramics. Mohapatra and Rao (2001) review some aspects related to the use and environmental effects of fly ashes in general, resulting from the burning of municipal solid waste, fossil fuel, coal, etc. Reijnders (2005) discusses disposal practices, uses and treatments for combustion ashes (from coal, wood, agriculture residues, MSWI, etc.), taking into account the associated pollution, which is mainly provoked by leaching processes.

Some of the applications that have been researched for cement or concrete materials are shown in Table 13, for ceramic or glass-ceramics in Table 14, and other applications such as chemical conditioner for sludges and zeolites in Table 15, indicating where possible the type of ash tested. A possible classification of tested applications for FA/APC residues from MSWI, in accordance with some of these recent studies, is indicated in Fig. 9.

Among possible applications, ceramic or glass-ceramic materials could be a good option, and indeed, some patented processes may be found (Talmy et al., 1996). Our research group is involved in a project to assess the possibility of producing lightweight aggregates (LWA) from
APC residues. Although the APC residues do not improve the technical properties of LWA, the results obtained show that when the amount of waste used is lower than $3 \%(w t)$, or for the case of pre-washed residues lower than $5 \%$, the aggregates produced may have acceptable commercial properties. The amounts released through leaching processes for inorganic species are very low, and so the environmental impact is not significant.

The production of synthetic aggregates from combustion ashes has also been assessed in other research studies where several types of waste were tested (Wainwright and Cresswell, 2001). Concerning cement/concrete applications, the APC residue has limited performance, mainly due to the deleterious effect of the soluble salts, and in particular due to chlorides and sulphates. Moreover, the presence of materials such as aluminium may cause expansion due to the release of hydrogen; the ferrous metal can provoke staining of concrete; and soluble lead and zinc salts may interfere with the setting of cement. Ampadu and Torii (2001) state that the ecocement produced is designed to take advantage of the amount of chlorides in the incinerator ashes in order to obtain rapid-hardening cement. During the sintering process, chloride combines with calcium aluminate to form calcium chloroaluminate in place of tri-calcium aluminate. The performance of ecocement 
Table 12

Treatment of APC residues by combined methods (separation, S/S and/or thermal)

\begin{tabular}{lll}
\hline Methods & Residue & Method/ Objective \\
\hline Chemical (phosphate) & APC & (i) $\begin{array}{l}\text { Mix the residue with water }(L / S=2) \text { and } \\
2 \% \text { of } \mathrm{Ca}(\mathrm{OH})_{2} \text { and } 6 \% \text { of } \mathrm{H}_{3} \mathrm{PO}_{4} \text { during } \\
\text { Thermal (calcination) }\end{array}$ \\
& \\
& (ii) $\begin{array}{l}30 \text { min at room temperature } \\
\text { of the solid at } 900^{\circ} \mathrm{C} \text { in a muffle }\end{array}$
\end{tabular}

Separation (washing) S/ ESP $\mathrm{S}$ (Portland cement ASTM Type I)

Separation (washing)

FA

Stabilization

(phosphate)

Thermal (calcination)

S/S(cement)

Separation (washing)

FA

Stabilization

(phosphate)

Thermal (calcination)

Stabilization (iron oxide) APC Thermal (calcination) ESP
Washing process: (2 stages with water, $L / S$ ratio $=25,15 \mathrm{~min}$ ). The wastewater treatment is done by reducing of the $\mathrm{pH}$ and precipitating aluminium ion as metal hydroxide. The $\mathrm{Cd}, \mathrm{Pb}$ and $\mathrm{Zn}$ are adsorbed onto flock particles of aluminium hydroxide

S/S process: The sludge and washed residues were incorporated into cementitious materials (75 wt. \%)

A four stages treatment:

(i) water extraction during $1 \mathrm{~h}$ (water:solid wt ratio 8:1) for removing alkali chlorides. Filtering and washing the cake with 2 part of water

(ii) addition of a moderate quantity of phosphoric acid $\left(10 \mathrm{wt} \% \mathrm{H}_{3} \mathrm{PO}_{4}\right.$ - based on dry material)

(iii) calcinations up to $800^{\circ} \mathrm{C}$ in a oven, during $1 \mathrm{~h}$

(iv) solidification with Portland clinker or cement, for cement: ash ratios as low as 1:4 A three stages treatment:

(i) water extraction (water:solid wt ratio 2:1) in a stirred tank reactor of $10 \mathrm{~L}$ capacity;

(ii) $\mathrm{Ca}(\mathrm{OH})_{2}(20 \mathrm{~g})$ and $60 \mathrm{~g}$ of $\mathrm{H}_{3} \mathrm{PO}_{4}$ were added. The suspension was stirred for $30 \mathrm{~min}$ and then filtered with a filter-press.

(iii) The filter cakes were air-dried in an oven at $60{ }^{\circ} \mathrm{C}$ and calcinated under air atmosphere at $900{ }^{\circ} \mathrm{C}$ in a muffle furnace

The treatment consists of:

(i) APC residues were washed in a $\mathrm{FeSO}_{4}$ solution at a $L / S=5 \quad(2.5-5 \mathrm{gFe} / 100 \mathrm{~g}$ residue).

(ii) The solids were filtered and dried at $50^{\circ} \mathrm{C}$.

(iii) Bottom ash and dry iron-oxide-treated residues were mixed in a mass ratio of 9:1.

(iv) Heat treatment occurs at $900^{\circ} \mathrm{C}$ for $45 \mathrm{~min}$ (in a furnace with a static air atmosphere or in a tube furnace with a flow through of nitrogen).
Conclusion

Reference

By combining both chemical and thermal

Iretskaya treatments, an efficient stabilization of metals is found. The phosphate treatment reduces the

heavy metals solubility, and calcination allows apatite crystallization without evaporation of heavy metals

The combined washing and $\mathrm{S} / \mathrm{S}$ process is an appropriate method of optimizing the disposal of this material in cementitious matrices. Washed fly ash is transformed into a material that adversely affects cement hydration to a much lower extent than unwashed fly ash

The principal advantages of the process are: the PCDD/PCDF destruction, the reactivity of the heavy metals is much lower, the final solids have satisfactory mechanical properties, and the increase in weight of the waste to be disposed of does not exceed $1 / 4$

The alkali chlorides can be extracted by combining a calcium phosphate gel precipitation. $\mathrm{NaCl}$ and $\mathrm{KCl}$ can be obtained free from calcium salts, and the metals are immobilized in the calcium phosphate matrix. The calcination allows the formation of crystalline

hydroxylapatite, which may trap toxic metals and prevent their evaporation during thermal treatments

During washing treatment iron hydroxides precipitate and $\mathrm{Fe}(\mathrm{II})$ was oxidized by oxygen supplied from atmosphere due to stirring and bubbling over $24 \mathrm{~h}$. The sintering of the particles did not occur, but the process fixes the metals in the solid residue. This method of treatment produces a material that can be used as secondary road construction material
Derie

Mangialardi (2003)

(1996)

Nzihou

and

Sharrock

(2002)

Sorensen

et al.

(2001) is similar to the rapid hardening cement, but contains larger quantities of chlorides. Unlike the bottom ash produced during municipal solid waste incineration, which may be used under some circumstances for agricultural purposes (Zhang et al., 2001, 2002), APC residues are not recommended for this application due to their high concentration of heavy metals.

\section{Conclusions}

The main objective of this work has been to review possible management strategies, treatments and applications of APC residues produced during MSWI processes. These types of residues may be produced in units such as heat recovery systems - boiler, superheater and economiser, electrostatic precipitators, fabric filters or baghouse, through dry scrubbing, semi-dry scrubbing or wet scrubbing, or cyclone. From the literature analyzed, some conclusions may be drawn:

- these residues are in general considered hazardous waste, which means that they should not be used directly as raw material in environmental applications, and should be properly treated before landfilling; 
Table 13

Practical applications for valorization of APC in cement or concrete materials

\begin{tabular}{|c|c|c|}
\hline Product & Residue & Process/Conclusions \\
\hline Eco-cement & FA & $\begin{array}{l}\text { This study refers the characterization of ecocement pastes and mortars produced from } \\
\text { incinerated ashes. The technology for manufacturing ecocement was developed by New } \\
\text { Energy and Industrial Technology Development Organization (NEDO) of Japan. The } \\
\text { ecocement is produced similarly to the normal Portland cement by using up to } 50 \% \text { of } \\
\text { municipal waste incinerator ashes }\end{array}$ \\
\hline Cement & $\begin{array}{l}\text { ESP } \\
\text { FF }\end{array}$ & $\begin{array}{l}\text { Recycling these residues is possible through cement production. In a pilot plant, with a } \\
\text { capacity of } 50 \text { tons/day) } 0.5 \text { ton of incineration ash, } 0.3 \text { ton of dry sewage sludge and } \\
0.3 \text { ton of limestone were converted to } 0.85 \text { ton of cement clinker. By adding } 0.15 \text { ton of } \\
\text { gypsum to the clinker, } 1.0 \text { ton of cement can be produced. It should be noted that an } \\
\text { adequate treatment of the waste is able to fix the chlorine through calcium- } \\
\text { chloroaluminate formation. The quality of the resulting cement is sufficient to enable the } \\
\text { practical use, and no secondary pollution was produced }\end{array}$ \\
\hline $\begin{array}{l}\text { Concrete (cement } \\
\text { replacement) }\end{array}$ & APC (WS) & $\begin{array}{l}\text { This study is centred on the analysis of the effects of the incorporation of APC ash in } \\
\text { cement pastes and mortars, by replacing cement with up to } 20 \% \text { MSWI fly ash. XRD } \\
\text { analysis revealed Friedel's salt, ettringite and thenardite resulting from the presence of } \\
\text { APC. The waste may increases mortar setting times and the compressive strength. } \\
\text { Strength reductions in the longer term (after } 565 \text { days) were observed in all the mortars } \\
\text { containing MSWI fly ash. The diffusion coefficients of cement pastes containing MSWI fly } \\
\text { ash were similar to the pure cement pastes }\end{array}$ \\
\hline
\end{tabular}
obtain slag samples, which were water-quenched and further pulverized. Such slag could be recovered in a more valuable form as a cement replacement than as a roadbed aggregate

Cellular mortar

\section{FA from} fluid sand furnace

\section{Aggregates for concrete}

\section{Aggregates for concrete}

Cementitious building materials

Blocks and pavement bricks

Aggregate for concrete

Asphalt for road FA

Marine applications ESP BA

Base layer for roads

$\mathrm{APC}+\mathrm{FA}$ treated (Ferroxprocess)
The considered FA can be used for producing cellular mortar because a significant content of aluminium, lime, sand and anhydrite is present. A mortar with $0.74-1.09 \mathrm{~kg} /$ $\mathrm{m}^{3}$ and a compressive strength of $3.9-8.5 \mathrm{~N} / \mathrm{mm}^{2}$ was produced in laboratorial experiments. This application tries to explore the advantage of the high quantity of aluminium that is present in the FA

After treatment (Revasol process: washing, phosphation and calcinations) the stabilized waste can be used in concrete as aggregate. From mechanical and durable points of view, the ash incorporated in the concrete behaves similarly to ordinary sand. The leaching testes show that the process makes it possible to obtain materials without major risks for the environment

A washing pre-treatment was applied to FA for removing sulfates and chlorides $(L /$ $S=10$, mixing during $20-30 \mathrm{~min}$, settling for $24 \mathrm{~h}$, filtration and drying solids at $105^{\circ} \mathrm{C}$ for $24 \mathrm{~h}$ ). In the $\mathrm{S} / \mathrm{S}$ treatment, cement, lime, sodium silicate, bentonite, blast-furnace slag, and water dosage of 30-40\% was used, and involves homogenization during $15 \mathrm{~min}$ and a curing phase during 15-20 days. The stabilized waste was ground $(<1.5 \mathrm{~mm})$ and the concrete is prepared with these aggregates

The FA of an incineration process, which previously separates metals, batteries, glass and ceramics were used to produce cementitious building materials. The considered FA exhibits pozzolanic action

Producing permeable blocks and pavement bricks from molten slag made by a surfacemelting furnace. The raw material is a mixture of bottom ash and bag house ash in a ratio of 3:1. This study shows an effective way of re-use of incineration residue slag and fly ash A four-stage washing treatment (stirring; $L / S=50$; mixing time $=30 \mathrm{~min}$ for each stage) was used for removing the water-soluble compounds almost completely. A compact pressure of $28 \mathrm{~N} / \mathrm{mm}^{2}$ is used in order to obtain cylinders of $1.5 \mathrm{~cm}$ in diameter and $2 \mathrm{~cm}$ in height, which are sintered at $1140{ }^{\circ} \mathrm{C}$ for $60 \mathrm{~min}$. The sintering of untreated MSW fly ashes proved to be unreliable

\section{acceptable}

The use of FA as filler in asphalt for road construction, is technical and environmental

The maximum quantity used is about $35 \%$ and a grinding phase is necessary

Marine applications of ESP and BA can be acceptable for locations with scarce land space (e.g. Bermuda). The testes should include sampling and characterization of waste, laboratory leaching testes, analysis of acute and chronic toxicity, baseline studies, establishment of acceptance criteria; modelling of the release of contaminants and assessment of environmental impact

The ashes were washed in a ferrous sulphate solution and afterwards aerated to transform the precipitated ferrous hydroxide into ferrihydrite (high capacity for binding the heavy metals). After blend $50 \mathrm{~kg}$ of cement, $80-100 \mathrm{~L}$ of water, $2150 \mathrm{~kg}$ of gravel or $1800 \mathrm{~kg}$ of aged BA and $110 \mathrm{~kg}$ of Ferrox-treated ash, the mixture was cast into $150-\mathrm{mm}$ cubes that were sealed and cured at $20^{\circ} \mathrm{C}$. The obtained product would provide a base layer suitable for roads with the required strength
Reference

Ampadu and Torii (2001)

Kikuchi (2001)

Rémond et al (2002a,2002b)

Wang et al. (2001)

Alaejos and Leiro (2003)

Aubert et al. (2004)

Collivignarelli and Sorlini (2001)

Gerdes and Wittmann (1994)

Nishigaki (2000)

Mangialardi (2001)

Hundales (1994)

Hjelmar et al. (1994)

Cai et al. (2004) 
Table 14

Practical applications for valorisation of APC in ceramics or glass-ceramics

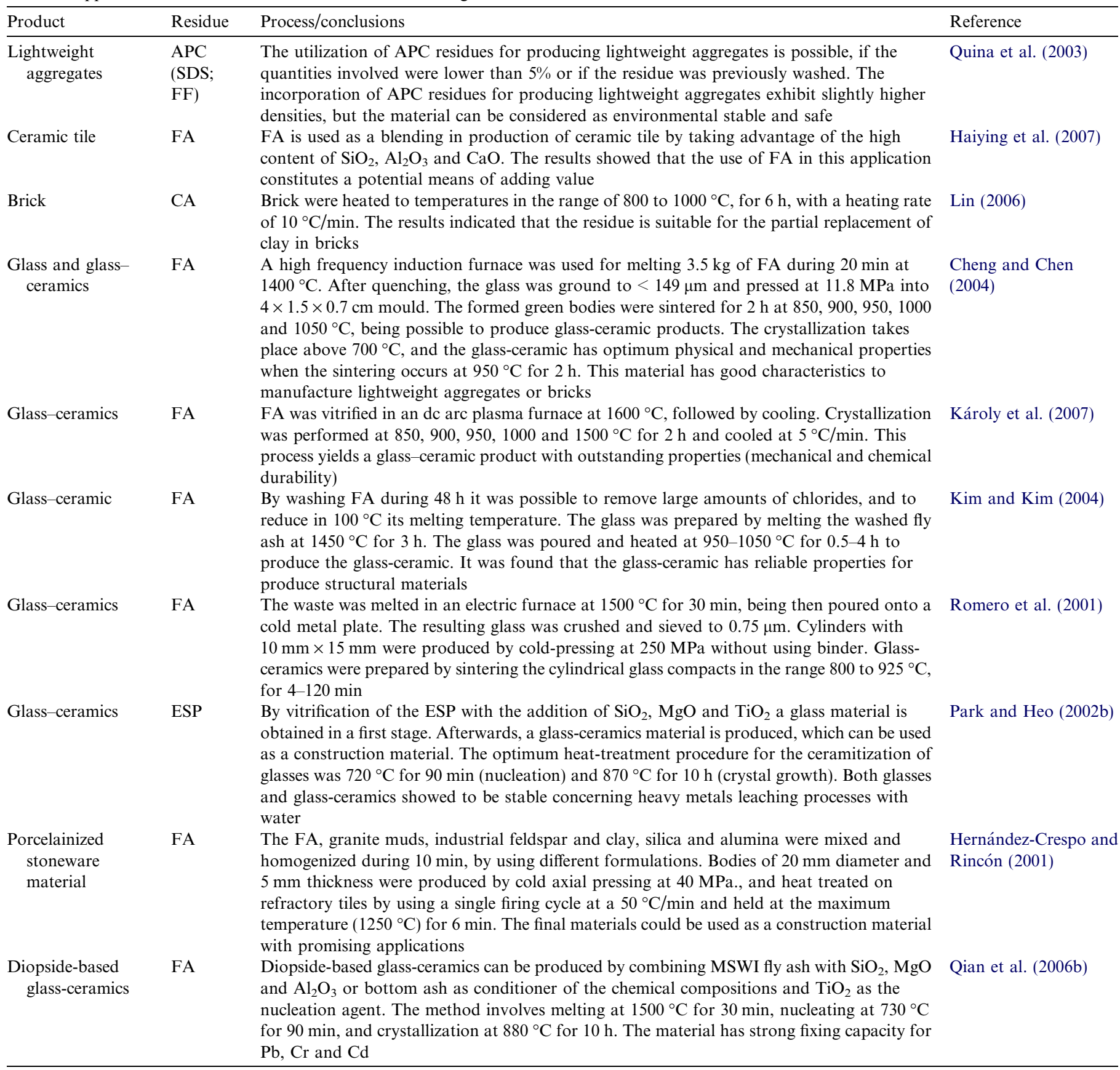

- landfilling in a specific disposal site is the most common strategy in Europe and America, although thermal methods are usually preferred in countries such as Japan;

- the main problems with these residues concern the high quantities of soluble salts, the significant amounts of some toxic heavy metals $(\mathrm{Pb}, \mathrm{Cd}, \mathrm{Cr}, \mathrm{Zn})$, and some trace organic compounds (e.g., dioxins, furans);

- possible treatments can be grouped into: separation processes: solidification/stabilization $(\mathrm{S} / \mathrm{S})$ treatments, and thermal methods;
- reliable results in terms of treatment and application may be obtained by combining two or more methods, e.g., washing treatment (for removing salts) followed by $\mathrm{S} / \mathrm{S}$ or thermal methods;

- although washing treatment can generate additional environmental problems, it results in a material that is suitable for further treatment or may have practical applications;

- in order to avoid landfilling, the valorization of the residues has been studied and several applications have been tested. The production of cement by using APC 
Table 15

Practical valorisation of APC in miscellaneous applications

\begin{tabular}{|c|c|c|c|}
\hline Product & Residue & Process/conclusions & Reference \\
\hline $\begin{array}{l}\text { Treatment of a waste } \\
\text { sludge }\end{array}$ & FA & $\begin{array}{l}\text { MSWI fly ash may be used as solidification binder to treat heavy metals-bearing industrial } \\
\text { waste sludge. The heavy metals-bearing sludge and MSWI fly ash have a strong fixing capacity } \\
\text { for } \mathrm{Zn}, \mathrm{Pb}, \mathrm{Cu}, \mathrm{Ni} \text { and } \mathrm{Mn} \text {. By using only } 5-15 \% \text { cement content was sufficient to achieve a } \\
\text { compressive strength of } 0.3 \mathrm{MPa} \text {. By mixing } 45 \% \text { fly ash, } 5 \% \text { cement and } 50 \% \text { of the industrial } \\
\text { sludge the required solidification and stabilization could be obtained }\end{array}$ & $\begin{array}{l}\text { Qian et al. } \\
\text { (2006a) }\end{array}$ \\
\hline Zeolites & $\mathrm{CA}$ & $\begin{array}{l}\text { The synthesis of zeolite-like materials by a hydrothermal alkaline processing is technically } \\
\text { possible, which are environmentally safe to use. Experimental parameters studied were the } \\
\text { mineralizer concentration, solid/liquid ratio, reaction time and operating temperature. The } \\
\text { main drawback is the produced effluent during the synthesis, which may contain high levels of } \\
\text { heavy metals }(\mathrm{Pb}, \mathrm{Zn}) \text { and require further treatment prior to discharge }\end{array}$ & $\begin{array}{l}\text { Yang and Yang } \\
(1998)\end{array}$ \\
\hline $\begin{array}{l}\text { Chemical conditioner } \\
\text { for sludges }\end{array}$ & FA & $\begin{array}{l}\text { The addition of fly ash can decrease the specific resistances and capillary suction time of oily } \\
\text { sludges up to } 3 \% \text { dosage, during the filtering process. Beyond } 3 \% \text { fly ash, the decrease is less } \\
\text { significant and the solids content in the sludge cake increases. The total suspended solids of } \\
\text { filtrate decrease with fly ash dosage but the toxic concentrations of heavy metals increases } \\
\text { considerably. However at the optimum dosage of } 3 \% \text {, concentrations of heavy metals are } \\
\text { within the limits for discharging into the sewers }\end{array}$ & $\begin{array}{l}\text { Tay and } \\
\text { Jeyaseelan (1997) }\end{array}$ \\
\hline
\end{tabular}

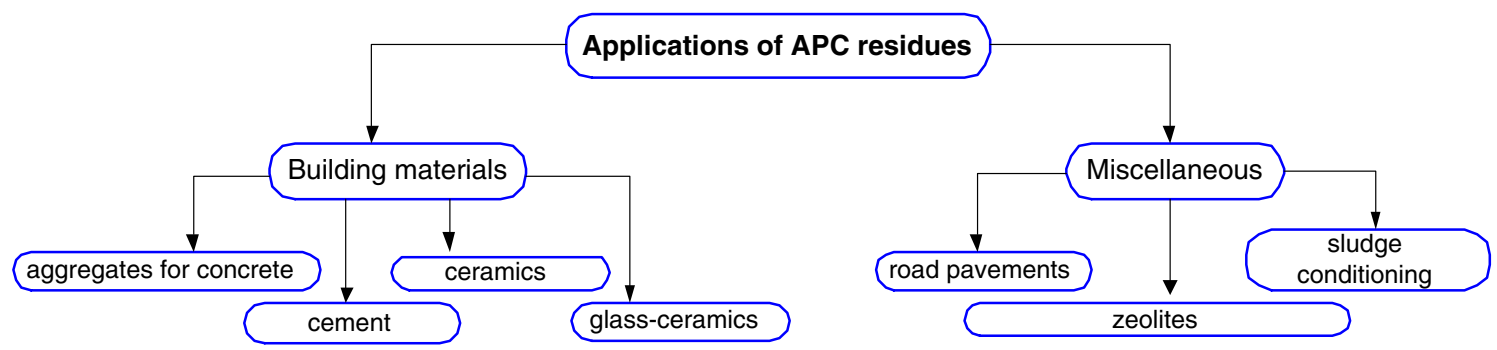

Fig. 9. Applications of APC residues tested in laboratory, pilot scale or industrial plants.

is unlikely to be a good solution due to the high quantities of soluble salts. Thermal treatments can produce a material that is environmentally stable, and may be further used for producing glass-ceramics;

- the production of lightweight aggregates by incorporating APC residues with natural clays is under investigation, and results have so far been promising.

\section{References}

Abe, S., Kambayashi, F., Okada, M., 1996. Ash melting treatment by rotating type surface melting furnace. Waste Manage. 16 (5/6), 431443.

Alaejos, P., Leiro, A., 2003. Utilization of municipal solid waste incinerator fly ashes to produce cellular mortars, In: Proceedings WASCON'2003, S. Sebastian, Spain, pp. 403-412.

Alba, N., Gasso, S., Lacorte, T., Baldasano, J.M., 1997. Characterization of municipal solid waste incineration residues from facilities with different air pollution control systems. J. Air Waste Manage. Ass. 47 (11), 1170-1179.

Alba, N., Vázquez, E., Gassó, S., Baldasano, J.M., 2001. Stabilization/ solidification of MSW incineration residues from facilities with different air pollution control systems. Durability of matrices versus carbonation. Waste Manage. 21 (4), 313-323.

Albus, J.F., Santora, S.A., 2003. Process and apparatus for vitrification of hazardous waste materials. US Patent no. 6620092.

Ampadu, K.O., Torii, K., 2001. Characterization of ecocement pastes and mortars produced from incinerated ashes. Cement Concrete Res. 31, $431-436$.
Aubert, J.E., Husson, B., Vaquier, A., 2004. Use of municipal solid waste incineration fly ash in concrete. Cement Concrete Res. 34 (6), 957-963.

Auer, S., Kuzel, H., Pollmann, H., Sorrentino, 1995. Investigation on MSW fly ash treatment by reactive calcium aluminates and phases formed. Cement Concrete Res. 25 (6), 1347-1359.

Auer, P.O., Eichler, B., Ludwing, C., Stucki, S., Wochele, J., 1999. Recycling heavy metals by the method of fractionated condensation. In: 4th World Congress - Recovery, Recycling, Re-integration, vol. IV, Geneve, pp. 328-333.

Bodénan, F., Deniard, P., 2003. Characterization of flue gas cleaning residues from European solid waste incinerators: assessment of various Ca-based sorbent processes. Chemosphere 51 (5), 335-347.

Bosshard, P.P., Bachofen, R., Brandl, H., 1996. Metal leaching of fly ash from municipal waste incineration by Aspergillus Niger. Environ. Sci. Technol. 30 (10), 3066-3070.

Cai, Z., Bager, D.H., Christensen, T.H., 2004. Leaching from solid waste incineration ashes used in cement-treated base layers for pavements. Waste Manage. 24 (6), 603-612.

Carignan, J., Libourel, G., Cloquet, C., Le Forestier, L., 2005. Lead isotopic composition of fly ash and flue gas residues from municipal solid waste combustors in France: implications for atmospheric lead source tracing. Environ. Sci. Technol. 39 (7), 2018-2024.

Carre, D., Templier, J.-C., 1995. Removal of heavy metals from fly ash and fume purification residues resulting from waste incineration. Patent no. WO/1995/022373.

Cartier, R., Longuet, T., Boen, R., Bres, J.-C., 1998. Treatment of fly ash produced by a waste incinerator and containing chlorides of toxic metals. US Patent no. 5716316.

Cheng, T.W., Chen, Y.S., 2004. Characterisation of glass ceramics made from incinerator fly ash. Ceram. Int. 30 (3), 343-349.

Chimenos, J., Fernández, A., Cervantes, A., Miralles, L., Fernández, M., Espiell, F., 2005. Optimizing the APC residue washing process to 
minimize the release of chloride and heavy metals. Waste Manage. 25 (7), 686-693.

Collivignarelli, C., Sorlini, S., 2001. Optimization of industrial wastes reuse as construction materials. Waste Manage. Res. 19, 539-544.

Conner, J.R., Hoeffner, S.L., 1998a. The history of stabilization/solidification technology. Crit. Rev. Environ. Sci. Technol. 28 (4), 325-396.

Conner, J.R., Hoeffner, S.L., 1998b. A critical review of stabilization/ solidification technology. Crit. Rev. Environ. Sci. Technol. 28 (4), 397 462.

Derie, R., 1996. A new way to stabilize fly ash from municipal incinerators. Waste Manage. 16 (8), 711-716.

Derie, R., 2000. Ash inerting method. US Patent no. 6132355.

Ecke, H., 2003. Sequestration of metals in carbonated municipal solid waste incineration (MSWI) fly ash. Waste Manage. 23 (7), 631-640.

Ecke, H., Sakanakura, H., Matsuto, T., Tanaka, N., Lagerkvist, A., 2000. State-of-the-art treatment processes for municipal solid waste incineration residues in Japan. Waste Manage. Res. 18 (1), 41-51.

Eighmy, T.T., Kosson, D.S., 1996. U.S.A. national overview on waste management. Waste Manage. 16 (5/6), 361-366.

Eighmy, T.T., Eusden, J., Krzanowski, J., Domingo, D., Stampfli, D., Martin, J., Erickson, P., 1995. Comprehensive approach toward understanding element speciation and leaching behavior in municipal solid waste incineration electrostatic precipitator ash. Environ. Sci. Technol. 29 (3), 629-646.

Eighmy, T.T., Crannell, B.S., Butler, L.G., Cartledge, F.K., Emery, E.F., Oblas, D., Krzanowski, J.E., Eusden, J.D., Shaw, E.L., Francis, C.A., 1997. Heavy metal stabilization in municipal solid waste combustion dry scrubber residue using soluble phosphate. Environ. Sci. Technol. 33 (11), 3330-3338.

Eighmy, T.T., Crannell, B., Krzanowski, J., Butler, L., Cartledge, F., Emery, E., Eusden, J., Shaw, E., Francis, C.A., 1998. Characterization and phosphate stabilization of dusts from the vitrification of MSW combustion residues. Waste Manage. 18 (6-8), 513-524.

Ferreira, C., Ribeiro, A., Ottosen, L., 2003. Possible applications for municipal solid waste fly ash. J. Hazard. Mater. 96 (2-3), 201-216.

Ferreira, C., Jensen, P., Ottosen, L., Ribeiro, A., 2005. Removal of selected heavy metals from MSW fly ash by the electrodialytic process. Eng. Geol. 77 (3-4), 339-347.

Frugier, P., Godon, N., Vernaz, E., Larché, F., 2002. Influence of composition variations on the initial alteration rate of vitrified domestic waste incineration fly-ash. Waste Manage. 22 (2), 137-142.

Gerdes, A., Wittmann, F.H., 1994. Use of ashes from MSW incineration in cementitious building materials. In: Proceedings of WASCON'1994, p. $905-908$.

Geysen, D., Imbrechts, K., Vandecasteele, C., Jaspers, M., Wauters, G., 2004a. Immobilization of lead and zinc in scrubber residues from MSW combustion using soluble phosphates. Waste Manage. 24 (5), 471-481.

Geysen, D., Vandecasteele, C., Jaspers, M., Wauters, G., 2004b. Comparison of immobilisation of air pollution control residues with cement and with silica. J. Hazard. Mater. 107 (3), 131-143.

Geysen, D., Vandecasteele, C., Jaspers, M., Brouwers, E., Wauters, G., 2006. Effect of improving flue gas cleaning on characteristics and immobilisation of APC residues from MSW incineration. J. Hazar. Mater. 128 (1), 27-38.

Glasser, F.P., 1994. Immobilisation potential of cementitious materials, Environmental Aspects of Construction with Waste Materials, Elsevier, WASCON' '94, pp. 77-86.

Glasser, F.P., 1997. Fundamental aspects of cement solidification and stabilization. J. Hazard. Mater. 52, 151-170.

Gougar, M.L.D., Scheetz, B.E., Roy, D.M., 1996. Ettringite and C-S-H portland cement phases for waste ion immobilization: a review. Waste Manage. 16 (4), 295-303.

Haiying, Z., Youcai, Z., Jingyu, Q., 2007. Study on use of MSWI fly ash in ceramic tile. J. Hazard. Mater. 141 (1), 106-114.

Hammy, F., Mercier, G., Blais, J.-F., 2005. Removal of lead in APCR leachates from municipal solid waste incinerator using peat moss in a batch counter-current sorption process. Hydrometallurgy 80 (4), 232 240.

Harada, Y., Takasuka, G., Kato, T., Hanai, Y., Kamei, H., Yamada, K., Otake, H., Itaya, M., 1992. Apparatus and process for treating waste incineration flyash. US Patent no. 5090338.

Haugsten, K.E., Gustavson, B., 2000. Environmental properties of vitrified fly ash from hazardous and municipal waste incineration. Waste Manage. 20 (2-3), 167-176.

He, P.-J., Zhang, H., Zhang, C.-G., Lee, D.-J., 2004. Characteristics of air pollution control residues of MSW incineration plant in Shanghai. J. Hazard. Mater. 116 (3), 229-237.

He, P.-J., Cao, Q.-K., Shao, L.-M., Lee, D.-J., 2006. Aging of air pollution control residues from municipal solid waste incinerator: Role of water content on metal carbonation. Sci. Total Environ. 359 (1-3), 26-37.

Hernández-Crespo, M., Rincón, J., 2001. New porcelainized stoneware materials obtained by recycling of MSW incinerator fly ashes and granite sawing residues. Ceram. Int. 27, 713-720.

Hjelmar, O., 1996a. Waste management in Denmark. Waste Manage. 16 (5/6), 389-394.

Hjelmar, O., 1996b. Disposal strategies for municipal solid waste incineration residues. J. Hazard. Mater. 47 (1-3), 345-368.

Hjelmar, O., Hansen, E.A., Andersen, K.J., Andersen, J.B., 1994. An approach to the assessment of the environmental impacts of marine applications of municipal solid waste combustion residues. In: Proceedings of the WASCON'1994, pp. 137-160.

Hong, K.J., Tokunaga, S., Kajiuchi, T., 2000. Extraction of heavy metals from MSW incinerator fly ashes by chelating agents. J. Hazard. Mater. 75 (1), 57-73.

Hu, S.-H., 2005. Stabilization of heavy metals in municipal solid waste incineration ash using mixed ferrous/ferric sulfate solution. J. Hazard. Mater 123 (1-3), 158-164.

Huang, W.J., Chu, S.C., 2003. A study on the cementlike properties of municipal waste incineration ashes. Cement Concrete Res. 33 (11), 1795-1799.

Huang, W.-J., Lo, J.-S., 2004. Synthesis and efficiency of a new chemical fixation agent for stabilizing MSWI fly ash. J. Hazard. Mater. 112 (12), 79-86.

Hundales, J.B.M., 1994. The use of MSW fly ash in asphalt for road construction, WASCON'1994, pp. 227-232.

IAWG (International Ash Working Group: Chandler, A.J., Eighmy, T.T., Hartlén, O., Kosson, D., Sawell, S.E., van der Sloot, H., Vehlow, J.), 1997. Municipal solid waste incinerator residues, Studies in Environmental Science, vol. 67, Elsevier Science, Amsterdam.

IEA (International Energy Agency), 2000. The management of residues from thermal processes, report produced by CRE Group on behalf IEA.

Iretskaya, S., Nzihou, A., Zahraoui, C., Sharrock, P., 1999. Metal leaching from MSW fly ash before and after chemical and thermal treatments. Environ. Prog. 18 (2), 144-148.

Ito, T., 1996. Vitrification of fly ash by swirling-flow furnace. Waste Manage. 16 (5/6), 453-460.

Izumikawa, C., 1996. Metal recovery from fly ash generated from vitrification process for msw ash. Waste Manage. 16 (5/6), 501-507.

Jakob, A., Stucki, S., 1997. Complete heavy metal removal from fly ash by heat treatment: control mechanisms and parameters. In: Congress Proceedings R'97-Recovery, Recycling, Re-integration, vol. III, pp. 51-55.

Jakob, A., Stucki, S., Kuhn, P., 1995. Evaporation of heavy metals during the heat treatment of municipal solid waste incinerator fly ash. Environ. Sci. Technol. 29 (9), 2429-2436.

Jakob, A., Stucki, S., Struis, R.W., 1996. Complete heavy metal removal from fly ash by heat treatment - influence of chlorides an evaporation rates. Environ. Sci. Technol. 30 (11), 3275-3283.

Jianguo, J., Jun, W., Xin, X., Wei, W., Zhou, D., Yan, Z., 2004. Heavy metal stabilization in municipal solid waste incineration fly ash using heavy metal chelating agents. J. Hazard. Mater. 113 (1-3), 141-146.

John, R.E., 1995. Thermal processing of fly ash. US Patent no. 5390611. 
Jung, C.H., Matsuto, T., Tanaka, N., 2005. Behavior of metals in ash melting and gasification-melting of municipal solid waste (MSW). Waste Manage. 25 (3), 301-310.

Kamon, M., Katsumi, T., Sano, Y., 2000. MSW fly ash stabilized with coal ash for geotechnical application. J. Hazard. Mater. 76, 265-283.

Károly, Z., Mohai, I., Tóth, M., Wéber, F., Szépvölgyi, J., 2007. Production of glass-ceramics from fly ash using arc plasma. J. Eur. Ceram. Soc. 27 (2-3), 1721-1725.

Katsuura, H., Inoue, T., Hiraoka, M., Sakai, S., 1996. Full-scale plant study on fly ash treatment by the acid extraction process. Waste Manage. 16 (5/6), 491-499.

Kauser, D.E., LaMastro, R.A., 1991. Method for treating incinerator ash. US Patent no. 5041398.

Kawakami, I., Esaki, M., Tetsuyama, I., Sumitomo, M., 1996. Immobilization of fly ash from msw incinerators and ash-melting furnaces. Waste Manage. 16 (5/6), 483-489.

Kikuchi, R., 2001. Recycling of municipal solid waste for cement production: pilot-scale test for transforming incineration ash of solid waste into cement clinker. Resour. Conserv. Recy. 31 (2), 137-147.

Kim, H.S., Kim, J.M., 2004. Glass-ceramic produced from a municipal waste incinerator fly ash with high $\mathrm{Cl}$ content. J. Europ. Ceram. Soc. 24 (8), 2373-2382.

Kinto, K., 1996. Ash melting system and reuse of products by arc processing. Waste Manage. $16(5 / 6), 423-430$.

Kirby, C., Rimstidt, J., 1994. Interaction of municipal solid waste ash with water. Environ. Sci. Technol. 28 (3), 443-451.

Kirk, D.W., Chan, C.C., Marsh, H., 2002. Chromium behavior during thermal treatment of MSW fly ash. J. Hazard. Mater. 90 (1), 39-49.

Krebs, W., Brombacher, C., Bosshard, P.P., Bachofen, R., Brandl, H., 1997. Microbial recovery of metals from solids. FEMS Microbiol. Rev. 20 (3-4), 605-617.

Krebs, W., Bachofen, R., Brandl, H., 2001. Growth stimulation of sulfur oxidizing bacteria for optimization of metal leaching efficiency of fly ash from municipal solid waste incineration. Hydrometallurgy 59 (23), 283-290

Kuo, Y.-M., Lin, T-C., Tsai, P.-J., 2004. Metal behavior during vitrification of incinerator ash in a coke bed furnace. J. Hazard. Mater. 109 (1-3), 79-84.

Kuramochi, S., Aichi, T., Asada, H., Yatsuduka, H., Inoguchi, K., Dohi, T., 2005. Method of wet treatment of fly ash, Patent no. WO/2005/ 040437.

Laethem, B., van Herck, P., Geuzens, P., Vandecasteele, 1994. Integrated treatment of MSW-residues: treatment of fly ash in view of metal recovery, WASCON'1994, pp. 525-538.

Le Forestier, L., Libourel, G., 1998. Characterization of flue gas residues from municipal solid waste combustors. Environ. Sci. Technol. 32 (15), $2250-2256$

Li, M., Hu, S., Xiang, J., Sun, L.-S., Li, P.-S., Su, S., Sun, X.-X., 2003a. Characterization of fly ashes from two chinese municipal solid waste incinerators. Energy Fuel. 17 (6), 1487-1491.

Li, C.T., Huang, Y.-J., Huang, K.-L., Lee, W.-J., 2003b. Characterization of slags and ingots from the vitrification of municipal solid waste incineration ashes. Ind. Eng. Chem. Res. 42 (11), 2306-2313.

Li, M., Xiang, J., Hu, S., Sun, L.-S., Su, S., Li, P.-S., Sun, X.-X., 2004. Characterization of solid residues from municipal solid waste incinerator. Fuel 83 (10), 1397-1405.

Lin, K.L., 2006. Feasibility study of using brick made from municipal solid waste incinerator fly ash slag. J. Hazard. Mater. 137 (3), 1810 1816.

Lundtorp, K., Jensen, D.L., Sorensen, M.A., Christensen, T.H., Mogensen, E.P.B., 2002. Treatment of waste incinerator air-pollution-control residues with $\mathrm{FeSO}_{4}$ : concept and product characterisation. Waste Manage. Res. 20, 69-79.

Lundtorp, K., Jensen, D.L., Sørensen, M., Mosbæk, H., Christensen, T.H., 2003. On-site treatment and landfilling of MSWI air pollution control residues. J. Hazard. Mater. 97 (1-3), 59-70.

Mangialardi, T., 2001. Sintering of MSW fly ash for reuse as a concrete aggregate. J. Hazard. Mater. 87 (1-3), 225-239.
Mangialardi, T., 2003. Disposal of MSWI fly ash through a combined washing-immobilisation process. J. Hazard. Mater. 98 (1-3), 225-240.

Mangialardi, T., Paolini, A.E., Polettini, A., Sirini, P., 1999. Optimization of the solidification/stabilization process of MSW fly ash in cementitious matrices. J. Hazard. Mater. 70 (1-2), 53-70.

Massardier, V., Moszkowicz, P., Taha, M., 1997. Fly ash stabilizationsolidification using polymer-concrete double matrices. Eur. Polym. J. 33 (7), 1081-1086.

Mechtersheimer, G., 2001. Process for vitrifying heavy-metal-containing residues having a chlorine content above $10 \%$ by mass and a melting furnace for carrying out the process. US Patent no. 6315810.

Mechtersheimer, G., Wieckert, C., 1998. Process for vitrifying residues from flue gas cleaning. US Patent no. 5848960.

Mercier, G., Chartier, M., Sauvageau, C., Roberge, G., 2002. Method for removing metals from air pollution control residues. US Patent no. 6500395.

Millrath, K., Roethel, F.K., Kargbo, D.M., 2004. Waste-to-energy - the search for beneficial uses. In: Proceedings of 12th Annual North American Waste to Energy Conference, May 17-19, Savannah, Georgia.

Mizutani, S., Yoshida, T., Sakai, S., Takatsuki, H., 1996. Release of metals from MSW I fly ash and availability in alkali condition. Waste Manage. 16 (5/6), 537-544.

Mizutani, S., van der Sloot, H., Sakai, S., 2000. Evaluation of treatment of gas cleaning residues from MSWI with chemical agents. Waste Manage. 20 (2-3), 233-240.

Mohapatra, R., Rao, J.R., 2001. Review - some aspects of characterisation, utilisation and environmental effects of fly ash. J. Chem. Technol. Biotechnol. 76, 9-26.

Mugica, J., Aguirre, P., Fresnillo, P., 1995. Vitrification de cenizas volantes con plasma. Ing. Quim., Abril, 137-142.

Mulder, E., 1996. Pre-treatment of MSWI fly ash for useful application. Waste Manage. 16 (1-3), 181-184.

Nagib, S., Inoue, K., 2000. Recovery of lead and zinc from fly ash generated from municipal incineration plants by means of acid and/or alkaline leaching. Hydrometallurgy 56 (3), 269-292.

Nicholson, J.P., 1978. Stabilized mixture. US Patent no. 4101332.

Nishida, K., Nagayoshi, Y., Ota, H., Nagasawa, H., 2001. Melting and stone production using MSW incinerated ash. Waste Manage. 21 (5), 443-449.

Nishigaki, M., 2000. Producing permeable blocks and pavement bricks from molten slag. Waste Manage. 20, 185-192.

Nzihou, A., Sharrock, P., 2002. Calcium phosphate stabilization of fly ash with chloride extraction. Waste Manage. 22 (2), 235-239.

Park, Y.J., Heo, J., 2002a. Vitrification of fly ash from municipal solid waste incinerator. J. Hazard. Mater. B91, 83-93.

Park, Y.J., Heo, J., 2002b. Conversion to glass-ceramics from glasses made by MSW incinerator fly ash for recycling. Ceram. Int. 28 (6), 689-694.

Park, K., Hyun, J., Maken, S., Jang, S., Park, J.-W., 2005. Vitrification of municipal solid waste incinerator fly ash using brown's gas. Energy Fuel. 19 (1), 258-262.

Pedersen, A.J., 2002. Evaluation of assisting agents for electrodialytic removal of $\mathrm{Cd}, \mathrm{Pb}, \mathrm{Zn}, \mathrm{Cu}$ and $\mathrm{Cr}$ from MSWI fly ash. J. Hazard. Mater. 95 (1-2), 185-198.

Pedersen, A.J., Ottosen, L.M., Villumsen, A., 2005. Electrodialytic removal of heavy metals from municipal solid waste incineration fly ash using ammonium citrate as assisting agent, J. Hazard. Mater. 122 (1-2), 103-109.

Piantone, P., Bodénan, F., Derie, R., Depelsenaire, G., 2003. Monitoring the stabilization of municipal solid waste incineration fly ash by phosphation: mineralogical and balance approach. Waste Manage. 23 (3), 225-243.

Polettini, A., Pomi, R., Sirini, P., Testa, F., 2001. Properties of Portland cement - stabilised MSWI fly ashes. J. Hazard. Mater. B 88, 123-138.

Qian, G., Cao, Y., Chui, P., Tay, J., 2006a. Utilization of MSWI fly ash for stabilization/solidification of industrial waste sludge. J. Hazard. Mater. 129 (1-3), 274-281. 
Qian, G., Song, Y., Zhang, C., Xia, Y., Zhang, H., Chui, P., 2006 b. Diopside-based glass-ceramics from MSW fly ash and bottom ash. Waste Manage. 26 (12), 1462-1467.

Quina, M.J., 2005. Treatment Processes and Valorization of APC Residues-Municipal Solid Waste Incineration, $\mathrm{PhD}$ thesis, University of Coimbra, Portugal.

Quina, M.J., Almeida, M.A., Santos, R., Bordado, J.M., Quinta Ferreira, R.M., 2003. Utilisation of a waste for producing lightweight aggregates, In: Proceedings of WASCON'2003, S. Sebastian, Spain, pp. 925-928.

Quina, M.J., Almeida, M.A., Santos, R., Bordado, J.C., Quinta-Ferreira, R.M., 2006. Prediction of solid waste incineration residues quantity for valorization in lightweight aggregates. Advanced Materials Forum III, 1731-1735.

Quina, M.J., Santos, R.C., Bordado, J.C.M., Quinta Ferreira, R.M., 2007. Characterization of air pollution control residues produced in a municipal solid waste incinerator in Portugal. J. Hazard. Mater., in press, doi:10.1016/j.jhazmat.2007.07.055.

Reijnders, L., 2005. Disposal, uses and treatments of combustion ashes: a review. Resour. Conserv. Recy. 43 (3), 313-336.

Rémond, S., Pimienta, P., Bentz, D.P., 2002a. Effects of the incorporation of Municipal Solid Waste Incineration fly ash in cement pastes and mortars, I. Experimental study. Cement Concrete Res. 32 (2), 303-311.

Rémond, S., Bentz, D.P., Pimienta, P., 2002b. Effects of the incorporation of Municipal Solid Waste Incineration fly ash in cement pastes and mortars, II: Modeling. Cement Concrete Res. 32 (4), 505-674.

Romero, M., Rincón, J.M., Rawlings, R.D., Boccaccini, A.R., 2001. Use of vitrified urban incinerator waste as raw material for production of sintered glass-ceramics. Mat. Res. Bull. 36, 383-395.

Sabbas, T., Polettini, A., Pomi, R., Astrup, T., Hjelmar, O., Mostbauer, P., Cappai, G., Magel, G., Salhofer, S., Speiser, C., Heuss-Assbichler, S., Klein, R., Lechber, P., 2003. Management of municipal solid waste incineration residues. Waste Manage. 23 (1), 61-88.

Sakai, S., 1996. Municipal solid waste management in Japan. Waste Manage. 16 (5/6), 395-405.

Sakai, S., Hiraoka, M., 2000. Municipal solid waste incinerator residue recycling by thermal processes. Waste Manage. 20 (2-3), 249-258.

Sakai, S., Sawell, S.E., Chandler, A.J., Eighmy, T.T., Kosson, D.S., Vehlow, J., van der Sloot, H.A., Hartlen, J., Hjelmar, O., 1996. World trends in municipal solid waste management. Waste Manage. 16 (5/6), 341-350.

Sasae, T., Nishida, T., Katayama, K., Oshima, M., 1996. Treating agent for making harmless and immobilizing fly ash containing noxious metals and a method for the immobilizing treatment using it. US Patent no. 5516974.

Sawell, S.E., Hetherington, S.A., 2001. Treatment of fly ASH/APC residues including lead salt recovery. US Patent no. 6319482.

Sawell, S.E., Chandler, A.J., Eighmy, T.T., Kosson, D., van der Sloot, H.A., Hartlén, J., Hjelmar, O., Vehlow, J., 1995. An international perspective on the characterisation and management of residues from MSW incinerators. Biomass Bioenergy 9 (1-5), 377-386.

Song, G.J., Kim, K., Seo, Y., Kim, S., 2004. Characteristics of ashes from different locations at the MSW incinerator equipped with various air pollution control devices. Waste Manage. 24, 99-106.

Sorensen, M.A., Koch, C.B., Stackpoole, M.M., Bordia, R.K., Benjamin, M.M., Christensen, T.H., 2000. Effects of thermal treatment on mineralogy and heavy metal behavior in iron oxide stabilized air pollution control residues. Environ. Sci. Technol. 34 (21), 4620-4627.

Sorensen, M.A., Mogensen, E.P.B., Lundtorp, K., Jensen, D.L., Christensen, T.H., 2001. High temperature co-treatment of bottom ash and stabilized fly ashes from waste incineration. Waste Manage. 21 (6), $555-562$.

Stegemann, J.A., Buenfeld, N.R., 2003. Prediction of unconfined compressive strength of cement paste containing industrial wastes. Waste Management 23 (4), 321-332.

Stucki, S., Jakob, A., 1997. Thermal treatment of incinerator fly ash: factors influencing the evaporation of $\mathrm{ZnCl}_{2}$. Waste Manage. 17 (4), 231-236.
Swithenbank, J., 2000. Fly ash treatment. US Patent no. 6105517.

Talmy, I.G., Haught, D.A., Martin, C.A., 1996. Ash-based ceramic materials. US Patent no. 5521132.

Tay, J.-H., Jeyaseelan, S., 1997. Conditioning of oily sludges with municipal solid wastes incinerator fly ash. Water Sci. Technol. 35 (8), 231-238.

Todorovic, J., Ecke, H., 2006. Demobilisation of critical contaminants in four typical waste-to-energy ashes by carbonation. Waste Manage. 26 (4), 430-441.

Todorovic, J., Ecke, H., Lagerkvist, A., 2003. Solidification with water as a treatment method for air pollution control residues. Waste Manage. 23 (7), 621-629.

Ubbriaco, P., Calabrese, D., 1998. Solidification and stabilization of cement paste containing fly ash from municipal solid waste. Thermochim. Acta 321 (1-2), 143-150.

Ubbriaco, P., Calabrese, D., 2000. Hydration behaviour of mixtures of cement and fly ash with high sulphate and chloride content. J. Therm. Anal. Calorim. 61 (2), 615-623.

Uchida, T., Itoh, I., Harada, K., 1996. Immobilization of heavy metals contained in incinerator fly ash by application of soluble phosphatetreatment and disposal cost reduction by combined use of "high specific surface area lime". Waste Manage. 16 (5/6), 475-481.

Van de Laar, H.T.M., Slagter, J., Duzijn, R.F., De Zeeuw, J.H., 1994. Quality improvement of MSW fly ash and APC residues from MSW incinerator Amsterdam-West using different immobilization process, WASCON'1994, pp. 811-820.

van der Bruggen, B., Vogels, G., Van Herck, P., Vandecasteele, C., 1998. Simulation of acid washing of municipal solid waste incineration fly ashes in order to remove heavy metals. J. Hazard. Mater. 57 (1-3), $127-144$

van der Sloot, H.A., 1996. Present status of waste management in the Netherlands. Waste Manage. 16 (5/6), 375-383.

van der Sloot, H.A., Kosson, D.S., Hjelmar, O., 2001. Characteristics, treatment and utilization of residues from municipal waste incineration. Waste Manage. 21 (8), 753-765.

Van Gerven, T., Geysen, D., Stoffels, L., Jaspers, M., Wauters, G., Vandecasteele, C., 2005. Management of incinerator residues in Flanders (Belgium) and in neighbouring countries. A comparison. Waste Manage. 25 (1), 75-87.

Vehlow, J., 1996. Municipal solid waste management in Germany. Waste Manage. 16 (5/6), 367-374.

Wainwright, P.J., Cresswell, D.J., 2001. Synthetic aggregates from combustion ashes using an innovative rotary kiln. Waste Manage. 21, 241-246.

Wang, K.-S., Chiang, K.-Y., Perng, J.-K., Sun, C.-J., 1998. The characteristics study on sintering of municipal solid waste incinerator ashes. J. Hazard. Mater. 59 (2/3), 201-219.

Wang, K.-S., Lin, K.-L., Huang, Z.-Q., 2001. Hydraulic activity of municipal solid waste incinerator fly-ash-slag-blended eco-cement. Cement Concrete Res. 31, 97-103.

Wang, K.-S., Sun, C.-J., Yeh, C.-C., 2002. The thermotreatment of MSW incinerator fly ash for use as an aggregate: A study of the characteristics of size-fractioning. Resour. Conserv. Recy. 35 (3), 177-190.

Wang, K.S., Lin, K.L., Lee, T.Y., Tzeng, B.Y., 2004. The hydration characteristics when $\mathrm{C} 2 \mathrm{~S}$ is present in MSWI fly ash slag. Cement Concrete Comp. 26, 323-330.

Wey, M.-Y., Liu, K.-Y., Tsai, T.-H., Chou, J.-T., 2006. Thermal treatment of the fly ash from municipal solid waste incinerator with rotary kiln. J. Hazard. Mater. 137 (2), 981-989.

Wiles, C.C., 1996. Municipal solid waste combustion ash: state-of-theknowledge. J. Hazard. Mater. 47 (1-3), 325-344.

Wunsch, P., Greilinger, C., Bieniek, D., Kettrup, A., 1996. Investigation of the binding of heavy metals in thermally treated residues from waste incineration. Chemosphere 32 (11), 2211-2218.

Yang, G.C., Chen, S.-Y., 1996. Statistical analysis of physicochemical properties of monoliths solidified from a municipal incinerator fly ash. J. Hazard. Mater. 45 (2-3), 149-173. 
Yang, G., Tsai, C., 1998. A study on heavy metal extractability and subsequent recovery by electrolysis for a municipal incinerator fly ash. J. Hazard. Mater. 58 (1-3), 103-120.

Yang, G.C., Yang, T.-Y., 1998. Synthesis of zeolites from municipal incinerator fly ash. J. Hazard. Mater. 62 (1), 75-89.

Yang, G.C., Chou, S.-W., Hsu, T.-F., 1998. Effects of chelant (EDTA) addition on properties of cement-solidified municipal incinerator fly ash. J. Hazard. Mater. 58 (1-3), 153-164.

Youcai, Z., Lijie, S., Guojian, L., 2002. Chemical stabilization of MSW incinerator fly ashes. J. Hazard. Mater. 95 (1-2), 47-63.
Zhang, F.-S., Itoh, H., 2006. Extraction of metals from municipal solid waste incinerator fly ash by hydrothermal process. J. Hazard. Mater. 136 (3), 663-670.

Zhang, F-S., Yamasaki, S.-I., Nanzyo, M., 2001. Application of waste ashes to agricultural land - effect of incineration temperature on chemical characteristics. Sci. Total Environ. 264 (3), 205-214.

Zhang, F.-S., Yamasaki, S.-I., Nanzyo, M., 2002. Waste ashes for use in agricultural production: I. Liming effect, contents of plant nutrients and chemical characteristics of some metals. Sci. Total Environ. 284 (1-3), 215-225. 